\title{
"STill Crazy after All These Years": SECTION 88 OF THE INDIAN ACT AT FIFTY
}

\section{KERRY WILKINS ${ }^{*}$}

Section 88 of the Indian Act, which provides, as a matter of federal law, for the application of much provincial law to Indians, is fify years old this year: an apt time to review what we know of its origins and to reflect on the impact it has had on the Canadian law of Aboriginal peoples. This article attempts just such an assessment.

As it turns out, we know very little about the reasons for s. 88 's enactment; when introduced, it attracted almost no scrutiny from the public, in Parliament, or even at Cabinet. In the years since, we have paid dearly for that inattention. By happenstance, it has managed to fulfill its original mandate to protect Aboriginal peoples' treaty rights from the impact of standards enacted provincially. In almost every other respect, however, s. 88 has given rise to confusion and 10 controversy, frustrating courts' efforts to apply it coherently. thwarting Aboriginal peoples' (and others') attempts to tell what mainstream law prescribes, and complicating otherwise routine tasks of enforcement and administration. It is, for these reasons, a provision overdue for reconsideration.
La clause 88 de la Loi sur les Indiens qui régit, en tant que loi fédérale, l'application de nombreuses lois provinciales sur les Indiens a cinquante ans cette année. Le moment est donc tout indiqué pour revoir ce que nous connaissons de ses origines et de nous pencher sur ses retombées sur le droit canadien des Autochtones. Cet article se veut une telle évaluation.

Il s'avere que nous savons peu de choses sur l'adoption de cette clause. Lorsqu'elle a été présentée, elle n'a pas vraiment attiré l'examen du public, du parlement ou mème du cabinet. Depuis, nous avons payé cher pour cette inattention. Elle $a$, par hasard, réussi à remplir son mandat original de protéger les droits issus des traités des peuples autochtones de l'effet des lois normales adoptées au niveau provincial. Cependant, dans presque tous les autres cas, la clause 88 a occasionné de la confusion et de la controverse, a frustré les efforts des tribunaux à l'appliquer de façon cohérente, contrevenant les essais des peuples autochtones (et des autres) à dire ce que le droit conventionnel régit et compliquant autrement les tâches routinières d'application et d'administration. Pour ces raisons, sa réévaluation s'impose donc.

TABLE of CONTENTS

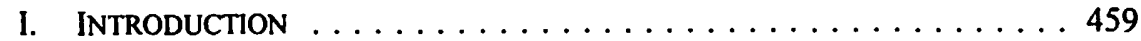

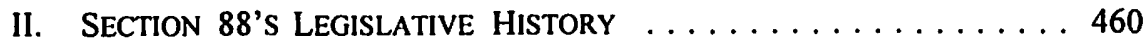

III. HOW PROVINCIAL LAWS APPLY:

WHAT SECTION 88 INCLUDES $\ldots \ldots \ldots \ldots \ldots \ldots \ldots \ldots$

IV. WHAT SECTION 88 EXCLUDES $\ldots \ldots \ldots \ldots \ldots \ldots \ldots \ldots 472$

A. "SUBJECt to THE TERMS OF ANy TREATY..." ........472

B. "... AND ANY OTHER ACT OF THE

Parliament of CanAda,..." ... . . . . . . . . . 477

C. "... All LAWS OF General ApPlication IN

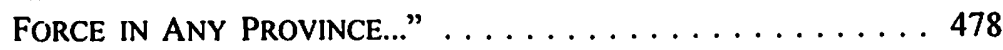

Of the Ontario bar. Special thanks to Kent McNeil, Eileen Hipfner, and an anonymous referee at the Alberta Law Review for their close reading of, and useful comments on, an earlier draft of this work; to John Leslie and his staff at DIAND's Claims and Historical Research Centre for giving me access to DIAND files and documents and for a helpful introduction to the task of research at the National Archives, and to Patrick Macklem and Tim McCabe for helping improve my thinking in formative early conversations about these difficult issues. Thanks finally to Kent and to John for pre-publication access to their own recent, related work. 


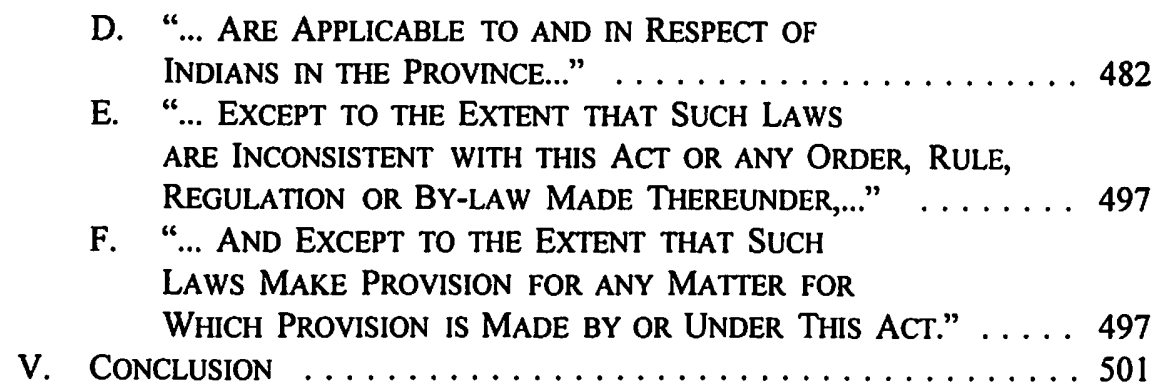

\section{INTRODUCTION}

Anyone seriously engaged in practicing the Canadian law of Aboriginal peoples is bound to encounter before very long $\mathrm{s} .88$ of the Indian Act. ${ }^{1}$ Section 88 provides expressly, as a matter of federal law, for the application of a great deal of provincial law to Indians. It reads as follows:

Subject to the terms of any treaty and any other Act of the Parliament of Canada, all laws of general application from time to time in force in any province are applicable to and in respect of Indians in the province, except to the extent that such laws are inconsistent with this Act or any order, rule, regulation or by-law made thereunder, and except to the extent that such laws make provision for any matter for which provision is made by or under this Act.

It was fifty years ago that s. 88 made its public debut as s. 87 of Bill 267, An Act Respecting Indians. ${ }^{2}$ On 7 June 1950, Walter Harris, Canada's Minister of Citizenship and Immigration, introduced Bill 267 in the House of Commons. The bill as a whole gave rise to concerted public and parliamentary opposition, partly on various substantive grounds and partly because of widespread resistance to enactment of such a sweeping revision of federal Indian law - the first such revision in seventy years without having given Indian leaders a meaningful opportunity to consider and comment on it. ${ }^{3}$ As a result, the government withdrew it before it proceeded to second reading. ${ }^{4}$ On 27 February 1951, however, Harris introduced Bill 79, a revised version of he earlier Indian bill. ${ }^{5}$ (The next day, he convened a conference of selected Indian leaders from across the country to review in detail the new bill's provisions.) ${ }^{6}$ The new bill

R.S.C. 1985 , c. I-5 [hereinafter Indian Act].

2d Sess., 21st Parl., 1950 [hereinafter Bill 267]. See House of Commons Debates (7 June 1950) at 3334.

3 See ibid. at 3938-45; 3968-77 (21 June 1950). John Diefenbaker, as it happens, was one of the bill's harshest critics on both of these grounds. See ibid. at 2205 (5 May 1950), 3331-32 (7 June 1950), 3973-76 (21 June 1950). For discussion of the public controversy over the bill, see J.F. Leslie, Assimilation, Integration or Termination? The Development of Canadian Indian Policy, 1943-1963 (Ph.D., Carleton University 1999) [unpublished] at 212-15.

House of Commons Debates (21 June 1950) at 3984.

Bill 79, An Act Respecting Indians, 4th Sess., 21st Parl., 1951 [hereinafter Bill 79].

For the official account of the proceedings of that conference, see "A Summary of the Proceedings of a Conference with Representative Indians Held in Ottawa, February 28-March 3, 1951" in House of Commons Debates (16 March 1951) at 1364-67 [hereinafter Indian Conference Report]. Compare Leslie, supra note 3 at 221-28. 
differed in several important respects from Bill $267^{7}$ but did preserve s. 87 intact. Bill 79, with some amendments, received initial Commons approval on 17 May 1951 and Royal Assent on June 21 of that year. ${ }^{8}$ It is, in most respects, the Indian Act we still have today. ${ }^{9}$

Ever since, for the past half century, s. $88^{10}$ has been with us, unamended. This anniversary offers occasion for a jubilee assessment of its provenance, its meaning, and its impact. As I hope to demonstrate here, few, if any, statutory provisions in force throughout these years have done quite so much to complicate or to confuse Canadian law.

\section{SECTION 88's LegisLATIVE History}

To the best of my knowledge, s. 88 was unprecedented. I know of no other statutory provision in federal law that says expressly that provincial law applies, as a general rule, to a class of subjects that the constitution assigns exclusively to federal legislative authority." This fact alone would give one good reason to expect s. 88 to have prompted significant public comment at the time of its introduction and to have received close review and thorough debate on its way through Parliament. One would, at a minimum, have expected to find on the public record some clear explanation of the government's rationale for promoting such a measure.

As far as I have been able to tell, ${ }^{12}$ no such discussion or explanation took place. Frankly, I was startled at how little public attention s. 87 (as it then was) attracted while before Parliament; ${ }^{13}$ still more surprising was the almost total absence of

For a comprehensive list of the 1951 revisions, see Memorandum, "Proposed Amendments to the Indian Act," NAC, RG 26, vol. 71 (25 April 1951) ("Miscellaneous re Indian Administration"). The Indian Act, S.C. 1951, c. 29. See Journals of the Senate of Canada (20 June 1951) at 401. John Leslie reports that "[t]he need to update branch field manuals and directives delayed proclamation until 4 September 1951": Leslie, supra note 3 at 237.

The principal changes, of course, have been to the rules for Indian registration and band membership: see R.S.C. 1985 (1st Supp.), c. 32, s. 4.

What had been s. 87 became s. 88 in the 1970 federal statute revision. See Indian Act, R.S.C. 1970 , c. I-6.

Section 91 of the Constitution Act, 1867 (U.K.), 30 \& 31 Vict., c. 3 [hereinafter Constitution Act, 1867 confers on the federal Parliament exclusive legislative authority over twenty-nine enumerated classes of subjects, including "Indians, and Lands reserved for the Indians" (s. 91(24)); its closing words expressly exclude from the heads of power assigned exclusively to provincial authority all matters that come within any of those twenty-nine specified classes of subjects.

There is almost certainly more historical information available about s. 88's origins than I have had opportunity to review. The departmental files from Indian Affairs and the Department of Justice that I had most hoped to review upon my visit to the National Archives - NAC, RG13, Series A-8, vol. 2737, file 97 ("Indian Act, 1948") and vol. 2759, file 31 ("Indian Act, 1952"), and the early years of DIAND file 1/1-8-3 ("Amendments to the Indian Act"), now catalogued at NAC, RG10, Acc. 1997-98/191, Boxes 2, 3, and 4- all were labelled "missing" in the records at the archives. Others interested in these issues may have better luck.

See, e.g., NAC, RG2, vol. 164, file I-14 ("Outside Correspondence about Bills 267 and 79"), 195051, which houses the correspondence about these bills to and from the Prime Minister. The only time s. 87 was mentioned in that correspondence was in a brief from the Indian Association of Alberta, dated 7 September 1950 . On page 8 of a clause-by-clause review of the whole of Bill 267, 
articulated justification for its enactment. Given the time and care devoted publicly during those years to the larger task of Indian Act revision, such silence seems truly remarkable.

It makes sense to begin the historical account with reference to that larger initiative. The 1951 amendments to the Indian Act concluded a process begun five years before, when the Senate and House of Commons established a special joint committee to examine federal Indian law and to consider possible revisions. ${ }^{14}$ The special joint committee spawned a royal commission, ${ }^{15}$ held three years of hearings into Indian affairs, ${ }^{16}$ issued substantive reports in 1946, 1947, and $1948,{ }^{17}$ and struck a subcommittee to prepare, in collaboration with federal Indian Affairs Branch officials,

it said of s. 87: "Approved; however, it must be clearly understood that no legislation, particularly with respect to hunting and fishing for food purposes, shall be interfered with."

To the best of my knowledge, the only other comment made about s. 87 at the time from outside government was that which appeared in the 1951 Indian Conference Report, supra note 6. According to that report, "[t]he conference delegates asked for clarification of $s .87$, dealing with the application of provincial laws, and was [sic] informed that provincial laws would not apply if they contravened any treaty, and/or any act of parliament, for example the Indian Act": ibid. at 1367 (para. 55). On the basis of that clarification, the provision was "accepted in principle by all of the representatives" at the conference: ibid. at 1366 (para. 36).

It might well be unwise, however, to make too much of this expression of acceptance from Indian leaders. John Leslie, who has written at length about the 1951 conference, describes it as "contrived" and "artificial" and documents the careful planning that went into the conference "in a conscious effort to control spreading Native political consciousness and activism" and to minimize, at the end of the conference, "any suggestion of Indian discontent or criticism": see Leslie, supra note 3 at 221-28.

See House of Commons Debates (13 May 1946) at 1446-48, 1492. For a very helpful overview of the process as a whole, see Leslie, supra note 3 at 112-243 and the sources cited there. See also Canada, Report of the Royal Commission on Aboriginal Peoples, vol. 1 (Ottawa: Minister of Supply and Services, 1996) at 307-14.

is Canada, "Report of the Commission on Indian Affairs" No. 68B in Sessional Papers (1947) [hereinafter Commission report]. The commission's terms of reference were to continue, in the Maritime Provinces and eastern Quebec, the inquiry into the matters remitted for consideration to the special joint committee: ibid. at 1 (para. 1).

The official record of these proceedings - Canada, Parliament, Special Joint Committee of the Senate and the House of Commons appointed to examine and consider the Indian Act, Minutes of Proceedings and Evidence (Ottawa: Queen's Printer, 1946-48) - runs to several volumes. For a semi-official summary of the representations to the committec, see "Brief Synopsis of the Representations Made by Persons Appearing before the Special Joint Committee of the Senate and House of Commons" (27 November 1947), DIAND, Claims and Historical Research Centre Document No. J-19 [hereinafter Brief Synopsis]. See also Leslie, supra note 3 at 117-76; J. Leslie \& R. Maguire, eds., The Historical Development of the Indian Act, 2d ed. (Ottawa: DIAND, Treaties and Historical Research Centre, 1978) [hereinafter Historical Development] at 133-42. Sce, e.g., Journals of the House of Commons of Canada, (15 August 1946) [hereinafter 1946 report] at 701-703; ibid. (10 July 1947) [hereinafter 1947 report] at 761-64; ibid. (22 June 1948) [hereinafter 1948 report] at 647-51. Also available for review are the initial responses from the Indian Affairs Branch to the recommendations in the 1948 report. See Recommendations of the Special Joint Committee of the Senate and House of Commons, Fourth Report, Tuesday, June 22, 1948, DIAND, Claims \& Historical Research Centre Document No. J-15. 
draft legislation that would express the approach and the revisions it thought were appropriate. That draft bill was in many ways the prototype of Bill $267 .^{18}$

From these materials, one can draw two helpful conclusions about s. 88's provenance. It was, at a minimum, intended to perpetuate the statutory rights that the Indians already had to sue in tort, in contract, and for debts that came due. ${ }^{19}$ And it was meant, almost certainly, to address and acknowledge the widespread sense that provincial measures should not constrict the exercise of Indians' legitimate treaty rights. $^{20}$

See First Draft of Indian Bill [n.d.], NAC, RG26, vol. 71 ("Miscellaneous re Indian Administration"), also available as DIAND, Claims \& Historical Research Centre document No. J-4 [hereinatter First Draft]. This document, by its own description, is the "Draft of the Indian Bill known as the Joint Committee Draft with corresponding sections in Indian Bill 267 shown in marginal cross references": ibid. at 1. John Leslie dates the Joint Committee Draft from 8 June 1948: see Leslie, supra note 3 at 184. As this document demonstrates, Bill 267 incorporated without amendment many of the provisions in the Joint Committee Draft.

See R.S.C. 1927, c. 98, s. 106; First Draft, ibid. at 54-55. The earlier provision appeared, with only minor revisions, as s. 80 in the Joint Committee Draft. The marginal note, which links this text with Bill 267, said "Is not brought into the Act as this authority is contained in new draft s. 87 of Bill 267": ibid.

"Treaty rights and obligations" were the first of the eight enumerated items of business that comprised the mandates of both the special joint committee and the 1946 Royal Commission. According to the Royal Commission, the Indians who appeared before it believed that their treaties with the Crown were still binding on the federal Crown but complained that they "do not to-day enjoy the rights and privileges conferred on their ancestors by those treaties": Commission report, supra note 15 at 3-4 (para. 6(a)); it urged the special joint committee to give this issue special attention (ibid.). The special joint committee agreed to do so: see 1946 report, supra note 17 at 702 (para. 4). No less than forty-eight First Nations and other Aboriginal groups made similar representations in the proceedings before the special joint committee: see "Brief Synopsis," supra note 16 at $1 \mathrm{~A}$. Some non-native witnesses expressed the view that the Indian representatives were overestimating the amount of protection that their treaties gave them. See generally ibid. at 1-3; Leslie, supra note 3 at 138-44; Historical Development, supra note 16 at 133-42. The text of $\mathrm{s}$. 88 leaves room for both of these views.

In response to this testimony, the special joint committee twice recommended prompt establishment of a claims commission "to inquire into the terms of all Indian treaties, in order to discover and determine, definitely and finaily, such rights and obligations as are therein involved and, further, to assess and settle finally and in a just and equitable manner any claims or grievances which have arisen thereunder": 1948 report, supra note 17 at 648 (para. 1); compare 1947 report, supra note 17 at 762 (para. 2). The government considered and rejected that recommendation, preferring instead that Indians seek resolution in court of their treaty issues (see, e.g., NAC, RG2, Series A5a ("Cabinet Conclusions"), vol. 2647, NAC microfilm reel T-2367 (27 January 1951) at 2-3), but acknowledged the breadth and profundity of the concern about treaty issues: see House of Commons Debates (16 March 1951) at 1352-54; Canada, H.C., Special Committee appointed to consider Bill No. 79: An Act respecting Indians, Minutes of Proceedings and Evidence (Ottawa: Queen's Printer, April 1951) [hereinafter Special Committee proceedings] at 15-16 (16 April 1951). House of Commons debates dealt with treaty rights issues, and with the relationship between such rights and provincial law, on a number of occasions during those years: see, e.g., House of Commons Debates (21 March 1950) at 957-59; ibid. (21 June 1950) at 3943, 3964-65; ibid. (27 February 1951) at 715-16, 757; ibid. (16 March 1951) at 1351-52; ibid. (15 May 1951) at 3048-49. 
These, however, are both concerns that Parliament could as easily have addressed with other, more modest measures; neither required, in addition, affirmative federal statutory provision for the application of provincial laws to Indians. Neither, therefore, helps explain this substantial additional step.

The other clearly relevant theme that emerged from those deliberations was the growing federal conviction, identified most clearly in the 1948 report, that the provinces had a role to play in achieving the recognized long-term goal of assimilation - or, in a later idiom, "integration" 21 - of the Indian peoples into mainstream society. ${ }^{22}$ Section 88, at a minimum, was consistent with that conviction. ${ }^{23}$ Even here, though, Parliament, in enacting s. 88, went well beyond the special joint committee's recommendations. The approach recommended by the committee, ${ }^{24}$ and later endorsed explicitly by the federal minister, ${ }^{25}$ clearly emphasized cooperation, consultation, and coordination between the two orders of government in pursuit of the long-term objective. Nothing in these reports, and next to nothing in the public consultation

Later, during the House of Commons debate on Bill 267, Minister Harris would say that the "ultimate goal of our Indian policy is the integration of the Indians into the general life and economy of the country": see House of Commons Debates (21 June 1950) at 3938; compare ibid. (16 March 1951) at 1350. For commentary on the policy significance of this shift from talk of "assimilation" to talk of "integration," see Leslie, supra note 3 at 179-81. See 1948 report, supra note 17 at 651 (para. 12).

For this reason, I find it difficult to agree with Leroy Little Bear that s. 88, as a matter of legislative intention, "is a hunting reference ... simply declaratory of existing game laws" and not meant to be used "for the application of run-of-the-mill provincial legislation to Indians": see L. Little Bear, "Section 88 of the Indian Act and the Application of Provincial Laws to Indians" in J.A. Long \& M. Boldt, eds. Governments in Conflict? Provinces and Indian Nations in Canada (Toronto: University of Toronto Press, 1988) [hereinafter Governments in Conflict?] 175 at 184. The 1948 report, supra note 17, noted (at 651 (para. 12)) "certain aspects of Indian Affairs Administration which, perforce, require co-operation between Dominion and Provincial officials, to bring about the future economic assimilation of Indians into the body politic of Canada" and recommended that Canada consider raising them for discussion at the next Dominion-Provincial Conference. "[T]he matters above enumerated," it continued,

are matters which, normally, are dealt with under provincial legislative powers. However, it should be possible to arrive at such financial arrangements between the Dominion and Provincial governments as might bring Indians within the scope of such provincial legislation, in order that there be mutual and co-ordinated assistance to facilitate the Indians to become, in every respect, citizens proud of Canada and of the provinces in which they reside (ibid.).

In fact, the government chose to proceed without convening a federal-provincial conference on Indian issues: see, e.g., Special Committee proceedings, supra note 20 at 21 (16 April 1951). No such conference would take place until 1964. By then, the goal of arranging for "mutual and coordinated assistance" to Indians - and, especially, avoiding federal-provincial duplication in the delivery of services to Indians - had assumed substantial importance on the federal agenda. See, e.g., "The Administration of Indian Affairs," NAC, RG26, Series A2a, vol. 71 ("Miscellaneous re Indian Administration"), a federal discussion paper prepared for the 1964 conference, especially at $1-3,7$.

See Special Committee proceedings, ibid. at 21 (16 April 1951). Compare House of Commons Debates (16 March 1951) at 1354: "we should continue the policy of co-operation with the provincial governments in an effort to obtain the maximum conservation of game and fish, together with the continuing exercise of these rights granted to the Indians." 
informing them, ${ }^{26}$ encouraged or supported unilateral federal imposition of provincial legislative regimes on Indians.

In these circumstances, one naturally looks to the parliamentary record for some explanation of the federal government's decision to introduce s. 88 full strength. Unfortunately, I found nothing instructive in those records either. ${ }^{27}$ The House of Commons debates on Bills 267 and 79 make no mention of or reference to it at all; ${ }^{28}$ s. 87 (as it then was) was approved without debate during clause-by-clause study by the Committee of the Whole House. ${ }^{29}$ On each of the rare occasions on which the provision attracted comment during legislative deliberation, the federal spokespeople seemed concerned to minimize its impact on Indians, not to celebrate its advantages. ${ }^{30}$

Official federal Cabinet records offer no further assistance. Indian Act amendments came before Cabinet for discussion no fewer than fifteen times between the release, in 1948 , of the final report of the special joint committee and the enactment, in 1951, of Bill 79. The Cabinet minutes from those meetings disclose no discussion, let alone any corporate decision, about what was then $\mathbf{s .} 87$ or about any of the issues it raised." The Cabinet memoranda prepared and distributed on the Indian Act amendments for those meetings ${ }^{32}$ help explain why. None of those memoranda ever called the

26 I did discover a letter, dated I June 1948, from the B.C. Cattlemen's Association, urging the federal minister to amend the Indian Act to subject all Indian reserves to provincial trespass laws. See Letter from J.E. Fry to J.E. Glenn (1 June 1948), NAC, RG10, vol. 8583, file 1/1-2-16, pt. 3, NAC microfilm reel C-14219.

27 Small wonder, then, that Leroy Little Bear was able, some years ago, to say that no court had yet "attempted to discern the intent of Parliament with regard to section 88": see Little Bear, supra note 23 at 184.

See House of Commons Debates (7 June 1950) at 3329-34; ibid. (21 June 1950) at 3936-51, 3962 81; ibid. (22 June 1950) at 3984; ibid. (27 February 1951) at 713-34, 752-59; ibid. (16 March 1951) at 1350-60; ibid. (2 April 1951) at 1522-37; ibid. (15 May 1951) at 3039-50, 3059-73, 308286; ibid. (17 May 1951) at 3106-12; ibid. (7 June 1951) at 3795. The section did receive brief mention, in passing, at the outset of second reading debate on the bill in the Senate: see Senate Debates (23 May 1951) at 458: "Provincial laws of general application are made applicable to Indians; subject, however, to the terms of any treaty, the Indian Act, and any other Act of the Parliament of Canada."

29 See House of Commons Debates (15 May 1951) at 3073.

30 I have found three such occasions. The first appeared in the Indian Conference Report, supra note 6 at 1367 (para. 55), quoted supra note 13. The second occurred when Bill 79 received detailed consideration by the special Commons committee: see Special Committee proceedings, supra note 20 at $167-71$ ( 23 April 1951). The third was during the Senate debate: see quotation at supra note 28.

31 The relevant dates are: 17 November 1948; 15 December 1948; 10 August 1949; 20 October 1949; 4 May 1950; 23 May 1950; 30 May 1950 (approving the introduction of Bill 267); 31 May 1950; 6 June 1950; 13 December 1950; 21 December 1950; 27 January 1951; 7 February 1951 (approving the introduction of Bill 79); 23 February 1951, and 16 April 1951: see NAC, RG2, Series A5a ("Cabinet Conclusions"), vols. 2642-47 (1948-1951), NAC microfilm reels T-2366, T2367. Nowhere do the Cabinet minutes record any discussion of, or decision specifically about, s. 87 or the issues it raised.

32 See Cabinet documents nos. 797 (12 November 1948), 824 (9 December 1948), both NAC, RG2 (18), vol. 66, file C-20-5; documents nos. 1003 (3 August 1949), 1068 (12 September 1949), both NAC, RG2(18), vol. 124, file C-20-5; documents nos. 133-50 (undated), 278-50 (5 December 1950), 284-50 (13 December 1950) and 295-50 (19 December 1950), all NAC, RG2(18), vol. 137, 
ministers' attention to s. 87 as such, to issues surrounding provincial laws or their application to Indians, or even to the relationship between provincial laws and treaty rights. ${ }^{33}$ On at least three occasions during those years, s. 87, as drafted, would have been directly germane to Cabinet's deliberations on other Indian Act amendments and on Indian policy generally. ${ }^{34}$

We live today with the consequences of that inattention. The next two Parts of this article review s. 88's judicial history and the profound doctrinal confusion and controversy to which s. 88 has given rise.

\section{How Provincial laws Apply: What Section 88 InCludes}

Section 88 displays a clear legislative expectation that provincial laws are to apply, for the most part, to Indians. That much, at least, has always been clear from its phrasing. Initially, though, it was much less clear how s. 88 contributes to realization of that expectation. Is it a mere declaration, for greater certainty, that the kinds of laws specified govern Indians in a province, subject to the restrictions and exceptions it sets out, ${ }^{35}$ or does it exist to ensure the application to Indians of those laws (subject, again, to the same exceptions and restrictions) by incorporating them by reference into federal legislation?

The Supreme Court of Canada struggled with this issue for several years in the course of its efforts to ascertain what kinds of powers the provinces themselves might

file C-20-5; document no. 31-51 (26 January 1951), NAC, RG2(18), vol. 138, file C-20-5, and an undated, unnumbered Cabinet memorandum from the period about certain possible Indian ACt revisions: NAC, RG26, vol. 71.

Available records do indicate that Cabinet members each received draft copies of Bill 79 on 31 January 1951, seven days before they were to approve it for introduction in the House: see NAC RG2, Series A5a ("Cabinet Conclusions"), vol. 2647 (7 February 1951) at 4, NAC microfilm reel $\mathrm{T}-2367$. It is reasonable to assume that they also received advance draft copies of Bill 267. They would, therefore, at least have had occasion to read s. 87 in context. In both bills' printed versions, however, the explanatory notes provided with $\mathbf{s .} 87$ said only that it was "New."

I refer here to the three occasions on which Cabinet considered, then finally rejected, the special joint committee's recommendation, discussed supra note 20 , that the government establish a claims commission to deal with Indians' treaty grievances: see NAC, RG2, Series A5a ("Cabinet Conclusions"), vol. 2645 (4 May 1950) at 7-8, NAC microfilm reel T-2366; vol. 2646 (21 December 1950) at 2-3, and vol. 2647 (27 January 1951) at 2-3, both NAC microfilm reel T-2367. One might have expected that Cabinet would note, in addressing the treaty grievance issue, that the legislation it was proposing to introduce contained a provision concerned with insulating treaty rights from provincial interference. There is, however, no official record that it did so, and none of the Cabinet memoranda submitted on that issue - Cabinet documents 295-50, 31-51 and the undated memorandum from NAC, RG26, Scries A2a, vol. 71, all supra note 32 - brought the connection to ministers' attention. 
have to affect the lives of Indians. ${ }^{36}$ The problem, as it seemed at the time, with the view that $\mathbf{s .} 88$ incorporates all provincial law by reference was the consequence that,

in respect of one class of persons, i.e., Indians, only federal law should apply to them, and subject to federal enforcement. It would mean that Parliament, by enacting s. 88, had caused valid provincial legislation, properly applicable to Indians, to cease to have effect as provincial legislation, by incorporating it as federal legislation into the Indian Act. $^{37}$

The problems with the "declaratory" view of s. 88, on the other hand, were that it left a long and complex statutory provision with very little real work to do, and that, so read, its closing words - "except to the extent that such laws make provision for any matter for which provision is made by or under this Act" - would have to be taken to be suggesting, falsely, that federal and provincial powers are concurrent, not exclusive. ${ }^{38}$ The fact that both sets of concerns made sense from a constitutional standpoint was a clear early indication that $\mathbf{s .} 88$ was going to pose problems.

It was only in 1985, in Dick v. $R .{ }^{39}$ that the court united behind a single approach to $\mathrm{s}$. 88. That approach takes its shape from a distinction "between two categories of provincial laws[:] ... provincial laws which can be applied to Indians without touching their Indianness, like traffic legislation[, and] provincial laws which cannot apply to Indians without regulating them qua Indians."40 "[I]t is," the court determined, "to the laws of the second category that s. 88 refers"; "[l "[l]aws of the first category," on the other hand, "continue to apply to Indians ex proprio vigore, as they always did before the enactment of s. 88 in $1951 \ldots$ and quite apart from s. 88."

We need some background in Canadian constitutional law to understand what the court is saying here. ${ }^{43}$ "Indians, and Lands reserved for the Indians" are among the classes of subjects that s. 91 of the Constitution Act, 1867 assigns exclusively to the

See, e.g., Cardinal v. Alberla (A.G.), [1974] S.C.R. 695 [hereinafter Cardinal] at 727-28, Laskin J. (dissenting); Natural Parents v. Superintendent of Child Welfare, [1976] 2 S.C.R. 751 [hereinafter Natural Parents] at 759-64, Laskin C.J.C. (for the plurality), 775-76, Martland J., 77881, Ritchie J.; Kruger \& Manuel v. R., [1978] 1 S.C.R 104 [hereinafter Kruger \& Manuel] at 11517; Four B Manufacturing v. United Garment Workers of America, [1980] 1 S.C.R. 1031 [hereinafter Four B] at 1048-49.

Natural Parents, ibid. at 776, Martland J. But see more recently Francis v. R., [1988] I S.C.R. 1025 [hereinafter Francis 88], where the court held that S. 6 of the Indian Reserve Traffic Regulations, C.R.C. 1978, c. 959 incorporates by reference provincial highway traffic laws for application on reserve but does not, by so doing, preclude those laws from applying there of their own force.

See Natural Parents, ibid. at 763-64, Laskin C.J.C.

[1985] 2 S.C.R. 309 [hereinafter Dick].

Ibid. at 326 .

Ibid. at 327.

Ibid. at 326.

For more detailed background on this, see K. Wilkins, "Of Provinces and Section 35 Rights" (1999) 22 Dalhousie L.J. 185 [hereinafter "Section 35 Rights"] especially at 191-213. See also N. Bankes, "Delgamuukw, Division of Powers and Provincial Land and Resource Laws: Some Implications for Provincial Resource Rights" (1998) 32 U.B.C. L. Rev. 317, especially at 329-33, 337-38. 
federal order of government and, by so doing, expressly subtracts from the ambit of provincial authority. ${ }^{44}$ This does not mean that Indians are altogether beyond the reach of provincial legislation or executive activity. Generally speaking, valid provincial measures - i.e., those whose primary subject matter is something within the proper scope of provincial authority - apply of their own force ("ex proprio vigore") to Indians, just as they would to anyone else, according to their terms. ${ }^{45}$ (Such laws are those in the first category that the Supreme Court identified in Dick. $)^{46}$ It does mean, though, that there is a certain more limited group of matters over which the provinces, acting as such, may exercise no mandatory control, either directly or indirectly. Each head of federal authority listed in s. 91 has a "basic, minimum and unassailable content": 47 a "core" set of matters from which it takes its definition. As the Supreme Court confirmed in Dick, the core of exclusive federal power over "Indians, and Lands reserved for the Indians" includes all matters characteristic of, or unique to, Indians as such: matters relating to "Indianness" or to Indians "qua Indians."48 Provincial measures that purport to make it their business to govern any such "core" matters are wholly invalid; such laws, altogether without legal force, have no application to anyone. But even otherwise valid provincial measures are "read down" as needed to ensure that they cannot have the effect, even inadvertently, of regulating core federal matters. ${ }^{49}$ This last group of provincial laws - those valid but inapplicable, as such, to Indians — are the ones in Dick's second category. ${ }^{\text {so }}$

What s. 88 does, then, according to the Supreme Court in Dick, is incorporate by reference, and apply as federal law, certain kinds of valid ${ }^{\text {s1 }}$ provincial measures - we shall think later about which kinds - that, for constitutional reasons, could not otherwise apply to Indians. It leaves undisturbed those provincial laws that apply of

4 Constitution Act, 1867, s. 91(24). See supra note 11 .

is This is equally true of other persons, places, or things assigned specifically to exclusive federal authority: see, e.g., Commission de la santé et de la sécurité du travail v. Bell Canada, [1988] 1 S.C.R. 749 [hereinafter Bell 88] at 762.

46. Supra note 40 and accompanying text.

47 Bell 88, supra note 45 at 839; Ordon Estate v. Grail, [1998] 3 S.C.R. 437 [hereinafter Ordon Estate] at 497 (para. 83).

48 See supra note $\mathbf{4 0}$ and accompanying text. Such matters include, among others, existing treaty and Aboriginal rights, including Aboriginal title (see, e.g., Simon v. R., [1985] 2 S.C.R. 387 [hereinafter Simon] at 411; Delgamuukw v. British Columbia (A.G.), [1997] 3 S.C.R. 1010 [hereinafter Delgamuukw] at 1119 (para. 178), matters related to Indian status and its necessary incidents (sce, e.g., Four B, supra note 36 at 1047-48), and matters related to the Indian character, identity, or relationship (see Natural Parents, supra note 36 at 761-63, Laskin C.J.C. (for the plurality), approved in Bell 88, ibid. at 834-36). See, e.g., Delgamuukw, ibid. at 1121 (para. 181); Ordon Estate, supra note 47 at $497-98$ (para. 83). For further explanation, see infra note 64 and accompanying text.

31) Supra note 40 and accompanying text.

si Section 88 cannot "invigorate" laws that have no independent force or effect: see, e.g., Dick, supra note 39 at 321-22; Delgamuukw, supra note 48 at 1122 (para. 182); P.W. Hogg, Constitutional Law of Canada, 4th ed. abridged (Toronto: Carswell, 1997) at 331. This restriction is merely an instance of the more general requirement that "the legislation which is incorporated by reference should have a validity and significance independent of the scheme of delegation": Hogg, ibid. at 331 . 
their own force to Indians or on Indian lands. Since 1985, the court has reaffirmed repeatedly and unanimously its support for this general proposition. ${ }^{52}$

The doctrinal advantage of Dick's approach is that it avoids the worst pitfalls of both the "declaratory" and the "universal incorporation" interpretations of s. 88. Unlike the "declaratory" view, it gives a constitutionally acceptable interpretation to s. 88's closing words; it is faithful to the exclusive nature of federal and provincial powers, ${ }^{53}$ and it does not purport to do what Parliament has no power to do: to prescribe the terms on which federal law will displace otherwise applicable provincial legislation. ${ }^{54}$ And

See, e.g., Derrickson v. Derrickson, [1986] I S.C.R. 285 [hereinafter Derrickson] at 296-97; Francis 88, supra note 37 at 1028-29, 1030-31; Côté v. R., [1996] 3 S.C.R. 139 [hereinafter Côté] at 191 (para. 86); Delgamuukw, supra note 48 at $1121-22$ (para. 182).

Supra note 38 and accompanying text.

[T] he concluding words of s. 88 are practically decisive: it would not be open to Parliament

in my view to make the Indian Act paramount over provincial laws simply because the

Indian Act occupied the field. Operational conflict would be required to this end. But

Parliament could validly provide for any type of paramountcy of the Indian Act over other

provisions which it alone could enact, referentially or otherwise:

Dick, supra note 39 at 327-28. For a view of this passage somewhat similar to mine, see K.J. Tyler, "The Division of Powers and Aboriginal Water Rights Issues" in National Symposium on Water Law (Canadian Bar Association, Environmental Law Section, 1999) 7.

Some commentators have taken issue with this proposition. Peter Hogg, for example, acknowledges its authority (coming, as it does, from a unanimous decision of the Supreme Court of Canada) but prefers the view that Parliament does have the power to prescribe, in legislation, a paramountcy rule: see Hogg, supra note 51 at 395-96. Bruce Ryder suggested, to similar effect, some years ago that this proposition may well preclude Parliament even from declaring explicitly that it "wants its legislation to be the sole applicable law" in a particular instance: see B. Ryder, "The Demise and Rise of the Classical Paradigm in Canadian Federalism: Promoting Autonomy for the Provinces and First Nations" (1991) 36 McGill L.J. 308 at 356, especially n. 207.

One needs to understand these concerns in context. Everyone agrees that the Constitution itself precludes provincial legislation, even when that legislation is valid and otherwise applicable, from interfering with the operation of valid federal law: see, e.g., Tennant v. Union Bank of Canada, [1894] A.C. 31 (P.C.) at 45; Ontario (A.G.) v. Canada (A.G.), [1894] A.C. 189 (P.C.) at 201; Reference re Provincial Court Judges, [1997] 3 S.C.R. 3 at 71 (para. 98). The only issue concerns the proper test for interference. In recent years, the Supreme Court has held that the federal legislation will neutralize the provincial legislation (i.e., assume "paramountcy" over it) in either of two circumstances: where there is a "practical and functional incompatibility" between the two schemes (see, e.g., Bell 88, supra note 45 at 866-67), or where the federal arrangements "display a sufficient intent that [the federal government] wished to cover the field exclusively": see, e.g., Francis 88, supra note 37 at 1031; Bank of Montreal v. Hall, [1990] I S.C.R. 121 at 151-55, and generally $R$ v. Chiasson (1982), 135 D.L.R. (3d) 499 (N.B.C.A.) at 508, aff d. (and reasons adopted) [1984] 1 S.C.R. 266. To this extent, it is clear that Parliament "constitutionally can demand paramountcy for its policies": see, e.g., Francis 88, ibid. at 1031, quoting B. Laskin, "Occupying the Field: Paramountcy in Penal Legislation" (1963) 41 Can. Bar Rev. 234 at 263.

So what is the Supreme Court trying to say here in this passage from Dick, ibid.? I believe it is saying that the federal order of government does not have the authority to decide unilaterally the terms on which its own laws will deprive provincial law of effect: to determine, in other words, the paramountcy rule. What constitutes interference, on this view, is a matter for judicial determination, based on the constitutional principles underlying the division of powers. I agree with this conclusion and, to that extent, disagree with Hogg. Unilateral federal power to make this kind of determination would amount, for all practical purposes, to a perpetual power of legislative disallowance. (Executive powers of disallowance are at least subject to limitation periods: see Constitution Act, 1867 , ss. 56, 90.) At the same time, I do not believe that the court's conclusion 
unlike the approach that contemplated "universal incorporation," it alleviates the risk that only federal law could apply to Indians; it leaves room for provincial law that has always applied, legitimately, to Indians to continue doing so. ${ }^{55}$

Doctrinally speaking, the impact of Dick is that $\mathbf{s . ~} 88$ is irrelevant - need not even arise for consideration - in a given case unless and until a court determines that the provincial law at issue is both constitutionally valid in its own right and, at the same time, constitutionally inapplicable, considered as provincial law, to Indians. ${ }^{56}$ Its impact, from a practical standpoint, is that a great deal of valid provincial legislation - even laws not yet in contemplation when s. 88 was enacted in $1951^{57}$ - is going

in Dick, ibid. is inconsistent with the proposition that Parliament "constitutionally can demand" paramountcy for particular arrangements. When federal authoritics demonstrate a clear intention that a given federal scheme is to operate to the exclusion of provincial law, they are not seeking to change the paramountcy rules that the courts have found in the constitution, but to operate within, and to take advantage of, them. Assuming that such a federal scheme is valid in every other respect, I see no reason why it could not operate as intended. To this extent, I disagree with Ryder. See supra note 37 and accompanying text.

s6 The Supreme Court itself has overlooked this consequence from time to time. In both Simon, supra note 48 (decided less than a month after Dick, supra note 39) and Quebec (A.G.) v. Sioui, [1990] I S.C.R. 1025 [hereinafter Sioui], the court relied on s. 88 to protect a treaty right from restriction by provincial law without first considering whether the provincial law in issue applied of its own force to the relevant Indians: see Simon, ibid. at 410-14, Sioui, ibid. at 1065-66. On other occasions, majority judgments have spoken loosely - in contexts where it did not affect the result - of provincial laws applying pursuant to $s .88$ without reference to the distinction in Dick, ibid. between provincial laws that apply of their own force and those that do not. See, e.g., Horseman v. R. [1990] I S.C.R. 901 at 936; Mitchell v. Peguis Indian Band, [1990] 2 S.C.R. 85 [hereinafter Mitchell] at 148, La Forest J. (for himself and two other judges on this issue); Badger v. R., [1996] I S.C.R. 771 [hereinafter Badger] at 809 (para. 69). In Dick, ibid., on the other hand, the s. 88 issue was essential to the outcome (see ibid. at 328). For that reason, and because the court has so often, in the years since, reaffirmed its support for the Dick approach (see supra note 52 and accompanying text), I remain of the view that, despite these departures, Dick is the law.

Dick, ibid., affirmed explicitly (at 328) the legitimacy of the practice of anticipatory incorporation by reference: adopting as law in the home jurisdiction whatever legislation (generally of a specified sort) a jurisdiction elsewhere may enact as its own. For criticism, on division of powers grounds, of this aspect of Dick, see Little Bear, supra note 23 at 184-86; Ryder, supra note 54 at 348, 375. For an earlier view, see K. Lysyk, "The Unique Constitutional Position of the Canadian Indian" (1967) 45 Can. Bar Rev. 513 at 531, 542-43. My own tentative view is that such incorporation, if achieved through otherwise valid legislative provisions, is, in principle, constitutionally permissible. The laws whose application depends on s. 88 apply as federal, not provincial law, and Canada probably is not enacting anything by means of it that it could not itself enact in equivalent terms. Compare Hogg, supra note 51 at 328-31, 569.

At the federal level, however, attempts at anticipatory incorporation, including s. 88, are complicated by other constraints that, so far at least, have attracted little attention. Federal statutes, like those of New Brunswick, Quebec, and Manitoba, have legal force only if printed and published in both official languages (Constitution Act, 1867, s. 133; Canadian Charter of Rights and Freedoms [hereinafter Charter], Part 1 of the Constitution Act, 1982 being Schedule B of the Canada Act, 1982 (U.K.), 1982, c. 11 [hereinafter Constitution Act, 1982], s. 18(1); Reference re Manitoba Language Rights, [1985] I S.C.R. 721). These requirements also apply to measures incorporated into federal (or New Brunswick, Quebec, or Manitoba) legislation; measures incorporated pursuant to s. 88, for instance, will have no force as federal law (assuming they do not yet exist in authoritative bilingual versions) unless federal officials can show that Parliament had a "bona fide reason for incorporation without translation" (Reference re Manitoba Language Rights, [1992] I S.C.R. 212 at 229). It is clear that there are reasons for incorporation without 
to be applying, one way or the other, to Indians. ${ }^{58}$ This result seems consistent enough with what S. 88 says and with what little we know of its legislative history. ${ }^{59}$ From a functional standpoint, however, these propositions, taken together, have some extremely troubling implications.

The problem is that the measures to which $\mathbf{s .} 88$ pertains govern everyone else within their intendment as provincial law but apply only as federal law to Indians. This means, in the first place, that such measures, when applied to Indians, are subject, as a matter of course, to federal procedures, policies, priorities, and discretion ${ }^{60}$ but to provincial priorities and procedures when applied to anyone else. ${ }^{61}$ This complication is headache enough for those charged with the administration of such measures, especially in the host of easily conjured situations involving both non-Indians and Indians. ${ }^{62} \mathrm{~A}$ second, related complication arises when we try to determine whose task it is to administer these measures. Provincial officials have full power to apply them to everyone else but none, while acting as such, to apply them to Indians. Any capacity such officials have to apply or enforce these laws in respect of Indians is necessarily delegated federal authority. Federal officials are, at best, in the same position, only with roles reversed. There seem to be only two administrative options available: asking officials from different orders of government to apply the same laws to different individuals, sometimes in the same situations, or asking officials from, say, the provincial order of

translation that courts, in proper circumstances, will consider bona fide (ibid. at 229-31); on the other hand, "[i]f a legislature incorporated wholesale the legislation of another jurisdiction which it could just as easily enact for itself, the action would clearly not meet the bona fide test": ibid. at 229-30. From this standpoint, anticipatory incorporation (sight unseen) of laws from another jurisdiction - especially on the scale contemplated by s. 88 - may well prove problematic because it operates automatically, not by way of case-by-case attentiveness to the weight of the constitution's translation requirement.

For criticism of the practical breadth of this approach, see Little Bear, ibid. at 183; Ryder, ibid. at $379-80$.

39) Supra notes 21-23 and accompanying text.

(4) See Natural Parents, supra note 36 at 776, Martland J., quoted in text supra at note 37 (provincial measures incorporated pursuant to $\mathbf{s .} 88$ are "subject to federal enforcement"). Compare Lysyk, supra note 57 at 543: "If provincial laws of any kind may only apply to reserve Indians by virtue of adoption by reference through s. 87 [now 88] of the Indian Act, they must of course be treated in all respects as federal laws." This means, for example, as Lysyk recognized (ibid.), that the Canadian Bill of Rights, S.C. 1960, c. 44, govems the application of such measures to Indians, but not to others.

It would be a denial of the basic concept of federalism to permit the provincial authoritics to have exclusive control of the enforcement of [the relevant federal] legislation and the sole determination as to how and when the legislation should be enforced by institution of prosecution or against whom such prosecution should be instituted. If the legislative field is within the enumerated heads of s. 91 [of the Constitution Act, 1867], then the final decision as to administrative policy, investigation and prosecution must be in federal hands:

R. v. Hauser, [1979] I S.C.R. 984 at 1004, Spence J. (concurring), approved in Canada (A.G.) v. CN Transportation, [1983] 2 S.C.R. 206 [hereinafter CN Transportation] at 238, 244 (confirming exclusive federal authority to determine who prosecutes offences created under federal law). See also St. Catherine's Milling \& Lumber v. R. (1889), 14 App. Cas. 46 (P.C.) [hereinafter St. Catherine's Milling] at 59 ("to ensure uniformity of administration," Constitution Act, 1867 placed control over Indian affairs "under the legislative control of one central authority"). reason to assume, without inquiry, that they will do so, either generally or on particular facts. 
government to operate in accordance with different priorities and policies (the federal and the provincial) in applying these same laws at the same time to Indians and to others. From a functional standpoint, neither option has much to recommend it.

These concerns themselves would be troubling enough, but it gets worse. One cannot always tell at a glance whether a given provincial measure applies, as such, to Indians or whether its application to them depends on $\mathbf{s .} 88$ because its effect is to regulate them "qua Indians." Such determinations are often profoundly difficult. ${ }^{63}$ Until they are made, however, there is no way of knowing, at least in difficult cases, which policies and procedures (the federal or the provincial) are to govern the application of these measures to Indians, or, perhaps, which officials (the federal or the provincial) have the power to carry out that aspect of their administration.

Finally, s. 88, by intervening to extend the application of certain provincial measures to Indians, is giving a reach to those measures that the provincial legislature must, for constitutional reasons, be taken to have intended that they not have. ${ }^{64}$ There is, at a minimum, room for doubt, in circumstances such as these, whether the federal order has constitutional authority to require that provinces assume the added financial and administrative burden of applying these hybrid measures beyond the permissible range of their application as provincial legislation. The Supreme Court has already held, in somewhat different contexts, that Parliament, acting unilaterally, does not have the power to impose on a province either the cost of federal enforcement activity undertaken within that province (even at the province's request) ${ }^{65}$ or the costs of delivering a valid federal program within a province or a municipality. ${ }^{66}$ It makes

And one cannot, of course, always tell just by looking whether a given individual is an Indian. Here, very briefly, is why. Both invalid provincial measures and those that are merely inapplicable would have the effect, if left alone, of governing matters outside the scope of provincial authority. What makes the invalid measure invalid, for purposes of the division of powers, is the court's conclusion that it displays a controlling intention to govern such matters. What protects the inapplicable measure from outright invalidity is the determination that it does not: that its overreaching, though impermissible, is inadvertent or incidental. The assumption underlying the doctrine of inapplicability is that the dominant intention of each of our legislative bodies is, in the absence of some clear indication otherwise, "to confine itself to its own sphere": see, e.g., Reference re Farm Products Marketing Act, [1957] S.C.R. 198 at 255.

Section 88's impact, however, is to bring certain matters lying outside the provinces' proper sphere - matters at the core of "Indianness," and therefore exclusive to federal authority - within the reach of a wide range of provincially enacted rules and standards. If a court, confronted with the provincial measure on its own, were to conclude that such a result was something that the provincial legislature had set out to accomplish, it would have no choice but to declare the measure invalid. See generally "Section 35 Rights," supra note 43 at 203-208. Section 88, therefore, operates despite - and because of - an overriding provincial intention that the relevant standard not govern matters related to "Indianness." See "Section 35 Rights," ibid. at 228-29. See Reference re Troops in Cape Breton, [1929] S.C.R. 554 at 562.

Nor has the respondent submitted any authority to support the proposition that, as incidental to the exercise of its legislative powers, Parliament can impose a financial burden upon an institution, such as a municipality, which is the creature of the Provincial Legislature, and whose powers, including the power to raise and spend money, are defined solely by provincial legislation:

Regional Municipality of Peel v. MacKenzie, [1982] 2 S.C.R. 9 at 19-20. See also ibid. at 22: "If the Parliament of Canada cannot impose on a province the duty to pay expenses, without its 
sense to expect the same result in respect of the extra costs that arise when Canada unilaterally extends, by incorporation, the application of a provincial scheme. If, therefore, the federal government contemplates provincial assistance in the administration of federal law and policy in matters beyond provincial legislative competence, it seems reasonable for the provinces to expect it to pay for that help. ${ }^{67}$ Efforts to identify the extra costs of administration that $\mathrm{s}$. 88 brings about are complicated substantially, however, by the uncertainty of speculating before the fact whether a given provincial measure applies to Indians (if at all) as provincial or as federal law.

Although s. 88, as interpreted, has indeed helped ensure that provincial standards will govern Indians, it has complicated greatly the tasks of applying and enforcing any of the provincial standards to which, in the end, it pertains. And these, remember, are the easy cases: the situations that do not engage the catalogue of restrictions, qualifications, and exceptions prescribed throughout s. 88. Most of these qualifications add new dimensions of complexity to the 5.88 inquiry. Each of them deserves independent attention.

In the next Part, I examine s. 88 phrase by phrase to study the internal restrictions it imposes on the application of candidate provincial measures.

\section{What SECTION 88 EXCLUDES}

\section{A. "SUbJECT to THE TERMS OF ANY TREATY ..."}

The laws that s. 88 incorporates into federal law apply to Indians "[s]ubject to the terms of any treaty"; where there is conflict between a treaty and some legislative provision to which s. 88 applies, the treaty prevails. ${ }^{68}$ We have known for some time

consent, it is my view that likewise it cannot, without the interposition of the province, impose such a duty upon municipal institutions in the province, created by the province pursuant to $\mathrm{s}$. 92(8) of [the Constitution Act, 1867]." But see also Reference re Goods and Services Tax, [1992] 2 S.C.R. 445, where the court concluded (at 484-85) that provinces, when they enter the commercial mainstream, are subject to the same obligations to collect and remit federal tax as any private operators engaged in similar businesses, and contemplated, without deciding, the scope of federal authority to impose administrative obligations on provinces unilaterally.

Recall that the special joint committee, when it promoted the goal of "bring[ing] Indians within the scope of such provincial legislation," emphasized the need for "such financial arrangements between the Dominion and Provincial governments as might" make this possible: see 1948 report, supra note 17 at 651 (para. 12), quoted more fully supra note 24.

See, e.g., R. v. George, [1966] 2 S.C.R. 267 [hereinafter George] at 281 (reference to treaties included in $\mathbf{5 . 8 8}$ "so as to preclude any interference with rights under treaties resulting from the impact of provincial legislation"); Kruger \& Manuel, supra note 36 at 114-15 ("The terms of the treaty are paramount; in the absence of a treaty provincial laws of general application apply"); Simon, supra note 48 at 410-14 ("it is clear that under s. 88 of the Indian Act provincial legislation cannot restrict native treaty rights. If conflict arises, the terms of the treaty prevail": ibid. at 413); Sioui, supra note 56 at 1065 ("Section 88 of the Indian Act is designed specifically to protect the Indians from provincial legislation that might attempt to deprive them of rights protected by a treaty"); $R$. v. Sundown, [1999] I S.C.R. 393 [hereinafter Sundown] at 418 (para. 47) ("The regulations in issue are provincial laws of general application that, if they were to apply to $\mathrm{Mr}$. 
now that the treaties that $\mathrm{s} .88$ protects do not include international treaties, even when international treaties contain provisions that confer specific protections on Indians. ${ }^{69}$ Section 88 protects only the treaties made between the Indians and the Crown. On the other hand, it protects all such treaties, not just treaties involving surrenders of land, ${ }^{70}$ and all the rights set out in those treaties - by exception, reservation, confirmation, or grant - not just those new rights that the treaties confer. ${ }^{71}$ For these purposes, "Parliament is to be taken," in giving meaning to the word "treaty," "to have had in mind the common understanding of the parties to the document at the time it was executed"; the term "embraces all such engagements made by persons in authority as may be brought within the term "the word of the white man." 72 In seeking to ascertain the legal nature of such an arrangement, the Supreme Court has instructed us to "adopt a broad and generous interpretation of what constitutes a treaty."

Section 88 , in other words, gives Indian treaties and treaty rights virtually complete protection $^{74}$ against the provincial laws to which it applies: better quality protection,

Sundown, would conflict with the treaty. Accordingly, they must give way to 'the terms of any treaty'"); and, most recently, Chippewas of Sarnia Band v. Canada (A.G.), (30 April 1999) (Ont. S.C.J.) [unreported] [hereinafter Chippewas of Sarnia] at 149 (para. 484) ("Section 88 cannot incorporate by reference any provincial law that infringes a treaty right. In no case has $\mathbf{s .} 88$ been found to incorporate referentially a provincial law that infringes a treaty right.")

This result, again, is consistent with Parliament's clear intention in enacting s. 88: see supra note 20 and accompanying text.

See Francis v. R., [1956] S.C.R. 618 [hereinafter Francis 56] at 631, Kellock J. (Jay Treaty of 1794). More recent lower court decisions, citing Francis 56 with approval, have held that the rights set out in international treaties are not among the "treaty rights" given constitutional protection by s. 35(1) of the Constitution Act, 1982. See R. v. Vincent (1993), 12 O.R. (3d) 427 (C.A.) (Jay Treaty); Mitchell v. M.N.R., [1997] 4 C.N.L.R. 103 (F.C.T.D.), aff'd. [1999] 1 F.C. 375 (C.A.) (Jay Treaty, Treaty of Ghent, and Treaty of Utrecht).

See Simon, supra note 48 at 410 ; Sioui, supra note 56 at 1042-43.

See Simon, ibid. at 409.

R. v. White and Bob (1964), 50 D.L.R. (2d) 613 (B.C.C.A.) [hereinafter While \& Bob] at 649, Norris J.A., aff'd. [1965] S.C.R. vi, 52 D.L.R. (2d) 491 quoted with approval in Simon, ibid. at 409-10, and Sioui, supra note 56 at 1035, 1041.

Sioui, ibid. at 1035.

"Virtually" complete protection because s. 88 is unlikely to protect from provincial law those treaty rights that, by the terms of the treaties in which they appear, are "subject to such regulations as may from time to time be made by the Government of the country": see, e.g., the texts of Treaties Nos. 4 and 7 as set out in A. Morris, The Treaties of Canada with the Indians of Manitoba and the North-West Territories (Toronto: Belfords, Clarke, 1880) at 333, 369, respectively. In Badger, supra note 56, the Supreme Court concluded (at 809-10 (para. 70)) that the "Government of the country" clause in Treaty No. 8 contemplates the application of provincial, as well as federal, game conservation laws to the treaty Indians. (For criticism of this conclusion, see "Section 35 Rights," supra note 43 at 211, n. 121.) Compare Sundown, supra note 68 at 413 (para. 38). Where this is so, the provincial law will likely operate on the right as an internal limit, derived from the terms of the treaty itself, not as a conflicting restriction imposed externally. In such circumstances, there will be no conflict between the provincial measure and the terms of the treaty, so s. 88 will not control the provincial measure's operation.

The federal government seems to have been aware of such arrangements when it introduced the bill that contained s. 88: see House of Common Debates (16 March 1951) at 1354. Sce also "Brief Synopsis," supra note 16 at 1-3. 
in fact, than such rights receive generally from s. 35(1) of the Constitution Act, 1982. ${ }^{75}$ The problem is that s. 88, as we saw above, incorporates, and applies exclusively to, a limited range of provincial measures. ${ }^{76}$ The protection that $\mathrm{s} .88$ affords to treaty rights, therefore, seems clearly to be available only against the effects of such laws as S. 88 incorporates: ${ }^{77}$ provincial laws "of general application" that cannot apply, as such, to Indians. ${ }^{78}$ Such rights derive no protection at all from s. 88 against the effects

See Côté, supra note 52 at 191-92 (para. 87). Section 35(1) protects existing Aboriginal and treaty rights from unjustified interference but permits constraints that can be justified: see, e.g., Sparrow v. $R$. [1990] 1 S.C.R. 1075 [hereinafter Sparrow] at 1109-10; Badger, supra note 56 at 811-16, 820-22 (paras. 73, 75-82, 85, 96-97). Section 88, on the other hand, makes no apparent allowance even for justified restrictions on treaty rights: see supra note 68 and accompanying text. For these reasons, I disagree with Robert Reiter's conclusion that "Section 35 now makes the treaty provisions of s. 88 obsolete": see R.A. Reiter, The Law of First Nations (Edmonton: Juris Analytica, 1996) at 196. See also ibid. at 209.

In Coté, ibid., the Supreme Court toyed briefly with the idea of bringing s. 88 into conformity with the justification regime developed pursuant to s. 35(1). Although "[t]he statutory provision does not expressly incorporate a justification requirement analogous to the justification stage in the Sparrow framework," Lamer C.J.C. observed (ibid. at 192 (para. 87)), "I know of no case which has authoritatively discounted the potential existence of an implicit justification stage under s. 88" (emphasis in original).

To me, this suggestion is inconsistent not only with the decided cases on $\mathrm{s.} 88$ (see, again, the quotations cited supra note 68), but with 5 . 88's legislative history: specifically, with the assurances given at the time by the minister to the Indian representatives "that provincial laws would not apply if they contravened any treaty" (see House of Commons Debates (16 March 1951) at 1367, quoted at greater length supra note 13), and to the members of the special Commons committee that considered Bill 79 that s. 87, as it then was, "does not affect their treaty rights at all" (see Special Committee proceedings, supra note 20 at 168 (23 April 1951)). Even apart from all that, however, it seems to me counterintuitive to suppose that Parliament, acting in 1951, intended treaty rights to have all and only the degree of protection that they would turn out later to obtain from a 1996 decision of the Supreme Court of Canada (Badger, ibid.) about a 1982 constitutional amendment. Anachronisms aside, I find it easy to imagine that a legislature might want to give greater protection to certain rights than they would derive, by default, from the Constitution. Labour relations and human rights codes seem obvious examples.

In Sundown, supra note 68, the Supreme Court declined (at 418 (para. 48)), in the circumstances of that case, an invitation to revisit this issue of "implicit justification" in the protection $\mathbf{5 .} 88$ extends to treaty rights.

I have heard it argued that $\mathrm{s.} 88$ can perform a double function: protecting treaty rights against the effects of all provincial laws while incorporating by reference only some of those laws. One possible reading of Côté, supra note 52 at 191 (para. 86) is consistent with this suggestion.

It seems to me likely that Parliament could, if it chose, enact a statutory scheme that did just that. My problem is that $\mathbf{s .} 88$ seems quite clearly not to be that scheme. The subject of the sentence that makes up s. 88 is "all laws of general application from time to time in force in any province"; those are the laws that are, at the same time, made "applicable to and in respect of Indians in the province" and made subject to all the exceptions in s. 88, including the exception giving priority to treaties. If only certain laws qualify for application to Indians pursuant to s. 88, then only those laws are subject to the restrictions that 5.88 imposes on their application. As the Supreme Court observed in Mitchell, supra note 56 at 124, "[i]t seems passing strange that the same words should be accorded different meanings in the same sentence." This must be so a fortiori in sentences where "the same words" occur only once.

Badger, supra note 56, is a clear demonstration of this. There, the Supreme Court bypassed entirely s. 88 and the protection it gives to treaty rights because the provincial measure in issue did not depend on s. 88 for its application. See ibid. at 809-10 (paras. 69-70). 
of provincial laws that apply of their own force. ${ }^{79}$ As the Supreme Court told us in Dick, s. 88 has nothing to do with those. ${ }^{80}$

Such a conclusion appears to encourage provinces seeking ways to control the exercise of treaty rights to engage in strategic drafting to avoid the reach of $\mathrm{s} .88 .{ }^{81}$ Any such possibility seems inconsistent with what we know of the legislative intent that animated this provision. As mentioned above, about the only thing that seems clear from the parliamentary record about $\mathbf{s .} 88$ is the intention that treaty rights prevail over conflicting provincial laws. ${ }^{82}$ This concern alone might well be enough to prompt us to reconsider the approach to s. 88 that the court approved in Dick, ${ }^{83}$ if there were a coherent alternative to it. ${ }^{84}$ Under ordinary circumstances, few courts would countenance a reading of a statutory provision so unsuccessful at realizing a clear legislative intention.

This would indeed be a troubling result if $\mathbf{s} .88$ were the only protection - apart from s. $35(1)$ of the Constitution Act, 1982 - that treaty rights had against provincial law. ${ }^{85}$ There is, however, strong authority ${ }^{86}$ buttressed by persuasive considerations

The cases have assumed that $\mathbf{s .} 88$ has this protective effect against all provincial laws, and they have not considered the implications of the Dick holding that s. 88 applies only to provincial laws that affect Indianness. According to Dick, s. 88 does not apply to provincial laws that do not affect Indianness, and therefore, s. 88 would not confer on Indian treaties paramountcy over provincial laws that do not affect Indianness:

Hogg, supra note 51 at 571 . See also Ryder, supra note 54 at 376.

See supra note 42 and accompanying text.

By, e.g., contriving measures that were not "laws of general application" for purposes of s. 88 . (For discussion of the "general application" requirement, see infra notes 102-19 and accompanying text.) Even if they succeeded, of course, they would, on this view, have to justify the controls they sought to impose, in accordance with s. 35(1) of the Constitution Act, 1982. The point is that they would, on this view, have the opportunity to do so: an opportunity that s. 88 would deny them, if it applied. See supra note 75 and accompanying text.

See supra notes 19-20, 75 and accompanying text.

See supra notes $39-55$ and accompanying text.

See supra notes 36-38, 53-55 and accompanying text.

Some, in fact, have argued that it is. See, e.g., P. Macklem, "First Nations Self-government and the Borders of the Canadian Legal Imagination" (1991) 36 McGill L.J. 382 at 436-42.

See, e.g., Simon, supra note 48 at 411 : "It has been held to be within the exclusive power of Parliament under s. 91(24) of the Constitution Act, 1867, to derogate from rights recognized in a treaty agreement made with the Indians." Compare Badger, supra note 56, where the Supreme Court, in a case about hunting rights protected by treaty, said (at 809 (para. 69)) that "the regulation of Indian hunting rights would ordinarily come within the jurisdiction of the Federal government and not the Province." See also White \& Bob, supra note 72 at 618, Davey J.A. (for the plurality), cited with approval in Kruger \& Manuel, supra note 36 at 113, Dick, supra note 39 at 324, and Simon, supra note 48 at 411 ; Hogg, supra note 51 at 566, especially n. 54.

Some may be tempted to argue that a passage from the Supreme Court's judgment on the rehearing application in Marshall v. R., [1999] 3 S.C.R. 533 [hereinafter Marshall (rehearing)] supports a contrary view. The court said there (at 551-52 (para. 24)) of its earlier judgment, on the merits, in that case (Marshall v. R., [1999] 3 S.C.R. 456 [hereinafter Marshall]) that it had been "most explicit in confirming the regulatory authority of the federal and provincial governments within their respective legislative fields to regulate the exercise of the treaty right subject to the constitutional requirement that restraints on the exercise of the treaty right have to be justified..." (emphasis added). 
of constitutional policy, ${ }^{87}$ to the effect that Indian treaty rights are matters integral, and therefore exclusive, to the federal government's constitutional authority over Indians and Indian lands. ${ }^{88}$ If this is so, then there is little danger of provincial measures, as such, constraining the exercise of such rights; generally speaking, the provinces simply have no power to do so. ${ }^{89}$ Insofar as provincial laws interfere with the terms of such treaties, therefore, they can have no relevant application except pursuant to s. 88. And

Personally, 1 doubt that this reference bears enough weight to anchor a change in the law. Considered as a summary of what the court had decided in Marshall, ibid., the passage is, in this one respect, inaccurate. Nowhere in Marshall's majority judgment does the court reflect on what powers, if any, the provinces may have to regulate treaty rights or their exercise. There was no occasion for it to do so; the appellant there had been charged with offences created under federal, not provincial, legislation. Considered as a fresh articulation of the law, the passage warrants caution, for at least four reasons. First, with one exception, the court does not mention, let alone distinguish or overrule, the earlier decisions (cited above), either its own or those it had approved from lower courts, that had held that treaties and treaty rights lie exclusively within federal authority. One would have expected some consideration of those precedents if the court's intention had been to prescribe a new direction. Second, the one case - Badger, ibid. - that the court does cite in the passage quoted from Marshall [rchearing] is, at best, equivocal authority on which to base a conclusion that provinces may regulate treaty rights. It is true that the court in Badger acknowledged, on the particular facts of that case, that the treaty right at issue there was subject to some provincial regulation. The court took pains to point out there, however, that the circumstances in that case were exceptional. In Badger, the provincial regulatory scheme applied (see ibid. at 809-10 (para. 70)) because of the combined effect of the "Government of the country" clause in Treaty $\# 8$ (see supra note 74) and para. 12 of the Alberta Natural Resources Transfer Agreement [hereinafter NRTA], which renders Indians subject to provincial "laws respecting game" "notwithstanding anything in the Constitution Act, 1867 or any Act amending the same": see Constitution Act, 1930 (U.K.), 20 \& 21 Geo. V., c. 26 [hereinafter Constitution Act, 1930]. But for those special arrangements, again, the regulation of such rights "would ordinarily come within the jurisdiction of the Federal government and not the Province": Badger, ibid. at 809 (para. 69). Third, the court was careful, in the passage from Marshall [rehearing], ibid., to confirm "the regulatory authority of the federal and provincial governments within their respective legislative fields to regulate treaty rights" (emphasis added). The scope of any provincial power to regulate treaty rights, therefore, continues to depend on the configuration of provincial legislative authority, in accordance with the usual rules for division of powers analysis: see, e.g., supra notes 43-50 and accompanying text. Nothing in Marshall [rehearing], ibid. suggests a departure from those rules or discourages the conclusion that provincial authority to regulate treaty rights remains constrained within the narrow limits set out in Badger. Finally, the passage takes no account of the impact on s. 88 of the view it is entertaining: see supra notes 74-84 and accompanying text. For discussion, see "Section 35 Rights," supra note 43 at 201-203.

nx At least insofar as such rights belong to those in the "core" group of peoples that qualify as "Indians" for purposes of s. 91(24) of the Constitution Acl, 1867. This group, in all likelihood, is both broader and narrower than the group of peoples that qualify as "Indians" under the statutory definition in the Indian Act: see "Section 35 Rights," ibid. at 195-96.

For a brief explanation why, see supra notes 43-50 and accompanying text. For more detail, see "Section 35 Rights," ibid. at 188-219.

This conclusion is subject to a few exceptions that apply in special circumstances: see ibid. at 20913. Chief among them for present purposes are those, mentioned briefly supra note 86 , on which the Supreme Court relied in Badger, supra note 56 at 809-10 (paras. 69-70): the "Government of the country" clauses in several numbered treaties (see supra note 74) and the special powers conferred upon the Prairie provinces, pursuant to the Constitution Act, 1930, by the NRTAs the federal government executed with those provinces. In neither of these situations, however, is s. 88 of any relevance: see Badger, ibid. at 809-10 (paras. 69-70). 
s. 88, as we saw, insulates the rights preserved, acknowledged, or confirmed in such treaties from the effects of the provincial laws it incorporates. ${ }^{90}$

It turns out, then, that s. 88 is in a position to protect Indian treaty rights from almost all provincial legislation." This is so, however, only because, and to the extent that, such legislation cannot in its own right govern the exercise of such rights. Properly understood, s. 88 gives treaty rights no independent protection from provincial activity; all it does is shelter this island of pre-existing incapacity from the current of referential incorporation as federal law for which it is more generally responsible.

\section{B. “... ANd Any Other ACt of the Parliament of Canada, ..."}

This phrase ensures that provisions in federal legislation other than the Indian Act take precedence, in case of conflict, over measures that s. 88 incorporates into federal law. (Other phrasing, later on in $\mathbf{5}$. 88, also ensures priority for the Indian Act's own provisions. $)^{92}$

From some standpoints, it may not be clear why such a provision is useful or necessary; the constitution itself already gives federal measures priority when provincial measures, though valid and applicable, interfere with their operation. ${ }^{93}$ What value does this specification in $\mathbf{s} .88$ contribute in light of existing paramountcy doctrine?

I believe the phrase is important because the situation that $\mathrm{s} .88$ addresses differs in two important ways from the standard scenario of federal/provincial conflict. First, as we have seen, s. 88 governs only those provincial laws that cannot apply of their own force to Indians. ${ }^{94}$ From a division of powers standpoint, no such laws can give rise, on their own, to questions of paramountcy; true paramountcy issues arise only where provincial and federal laws both apply of their own force. ${ }^{95}$ Second, the provincial laws to which s. 88 applies become, upon incorporation, federal legislation, at least in respect of their application to Indians. So understood, such measures no longer give way automatically when they clash with other federal laws; the issue is now one of statutory interpretation, not one of paramountcy. ${ }^{96}$ For these reasons, it was not only sensible but important for Parliament to prescribe an explicit hierarchy as between the free-standing federal laws and the $\mathbf{5}$. 88 hybrids. Because of this phrase, the free-

See supra notes $68-75$ and accompanying text.

" See Hogg, supra note 51 at 571,566 , especially $n$. 54. To the best of my knowledge, Hogg was the first to make this point in print.

92 See infra notes 193-94 and accompanying text. 
standing federal laws will displace the hybrids exactly when and as they would have done apart from s. 88. ${ }^{97}$

Unfortunately, s. 88 does not speak with similar clarity about the relationship between incorporated provincial measures and surviving pre-Confederation legislation including, perhaps most importantly, the Royal Proclamation of $1763 .{ }^{98}$ We know as a matter of general law that provinces, acting as such, cannot amend or repeal those parts of the Proclamation that deal with Indians' rights and that those provisions prevail over provincial measures, considered as such, that conflict with them.99 Once a provincial measure acquires the force of federal law pursuant to s. 88, however, it is from a constitutional standpoint of equal rank with the Proclamation and can operate to curtail the Proclamation's reach. Nothing in s. 88's own text precludes that result. ${ }^{100}$ Given the number and the explicitness of the other constraints that $\mathrm{s} .88$ imposes on the reach of the measures it governs, that omission itself may give courts reason not to protect the Proclamation from the impact of such measures. ${ }^{101}$

\section{C. “... All Laws of General Application in force in ANy Province ...”}

On its face, this phrasing is broad enough to capture federal, as well as provincial, laws of general application; they too, after all, are "in force in any province." We have known since 1966, though, that s. 88 "was not intended to be a declaration of the paramountcy of treaties over federal legislation" and that these words refer "only to

In Derrickson, supra note 52, the Supreme Court of Canada adopted Peter Hogg's view that these words "seem to be intended to make clear that the paramountcy doctrine applies to provincial laws, notwithstanding their adoption by a federal statute": see ibid. at 299-300, quoting from P.W. Hogg, Constitutional Law of Canada (2d ed.) (Toronto: Carswell, 1985) [hereinafter Hogg (2d ed.)] at 561-62. For the current reference, see Hogg, supra note 51 at 570 . R.S.C. 1985, App. II, No. 1 [hereinafter "the Proclamation"].

For a lucid and compelling explanation of these intricacies, see B. Slattery, "Understanding Aboriginal Rights" (1987) 66 Can. Bar Rev. 727 at 773, 777-78. Section 129 of the Constitution Act, 1867 continues pre-Confederation laws, including the Proclamation, in force until they are superseded by valid legislation enacted by the order of government having legislative authority over their subject matter. Because it was Parliament that acquired exclusive legislative authority over "Indians, and Lands reserved for the Indians," the relevant parts of the Proclamation continue as federal law, with priority over conflicting provincial law; only Parliament now has authority to amend or to repeal them.

100 Slattery offers an argument that the words "other Act of the Parliament of Canada" in s. 88, read in context, "do not refer exclusively to laws passed by Parliament but include all laws and acts in force in Canada that are subject to repeal by Parliament, including Crown acts prior to Confederation," including, of course, the Proclamation: see Slattery, ibid. at 779 (emphasis in original). I share his view that the law makes more sense if the Proclamation is insulated from the effects of incorporated provincial measures, but find his argument, though intriguing and wellreasoned, difficult to reconcile with the phrasing of $s .88$ itself. And as Slattery himself acknowledges (ibid., especially at n. 212), the lower courts addressing the issue have held that $s$. 88 does not give the Proclamation this protection. He cites as examples Kruger and Manuel $v$. $R$. (1975), 60 D.L.R. (3d) 144 (B.C. C.A.) at 147 (not considered in the S.C.C. decision, supra note 36); R. v. Tennisco (1981), 131 D.L.R. (3d) 96 (Ont. H.C.); R. v. Polchies (1982), 113 A.P.R. 449 (N.B.C.A.) at 454.

III) And, in fact, courts have held so far that s. 88 does not protect the Proclamation from incorporated provincial laws (see ibid.). 
those rules of law in a province which are provincial in scope."102 The reference, however, is not confined exclusively to laws the provinces have enacted since Confederation; it also includes "any [pre-Confederation] laws which were made a part of the law of a province" 103 as long as those laws count as laws of general application.

But what is a "law of general application"? The Supreme Court, in Kruger \& Manuel, ${ }^{104}$ prescribed two criteria, both of which a provincial law must satisfy to qualify as such a law for purposes of $\mathbf{s}$. 88. The first concerns the territorial reach of the relevant measure. To be "provincial in scope," 105 a law must "extend uniformly throughout the territory"; if it does not, "the inquiry is at an end and the question is answered in the negative." 106 For present purposes, this seems quite straightforward. $^{107}$ It means that laws aimed at particular territories within a province Toronto's recent "megacity" statute, ${ }^{108}$ for example - are, for that reason alone, ineligible for incorporation as federal law pursuant to s. 88. If some provision in such a measure has the effect, within its limited territorial reach, of regulating matters related to Indian lands, or to s. 91(24) Indians as such, it simply will not apply at all to those Indians or to those lands.

George, supra note 68 at 281 , subsequently quoted with approval (and emphasis) in Kruger \& Manuel, supra note 36 at 109 . There is at least some evidence that this conclusion replicates original drafting intentions: see infra note 216 and accompanying text. Compare Daniels v. White, [1968] S.C.R. 517, which held that the "game laws" provisions in the NRTAs between Canada and the Prairie provinces apply exclusively to provincial, not to federal, laws.

George, ibid. From a functional standpoint, it seems both inconvenient and incongruous that s. 88 would incorporate and give effect to pre-Confederation measures that are now within provincial scope, but, apparently, not protect from their impact the pre-Confederation measures now within federal scope: see supra notes $\mathbf{9 8 - 1 0 1}$ and accompanying text. This incongruity is part of Slattery's argument for a more inclusive reading of the phrase "any other Act of the Parliament of Canada": see Slattery, supra note 99 at 778 . The text of s. 88, however, invites just such distinctions. The reference to "all laws ... in force in any province" is considerably broader than the reference to "any other Act of the Parliament of Canada." Supra note 36.

See supra note 102 and accompanying text.

Kruger \& Manuel, supra note 36 at 110.

There are, however, some issues about this notion of uniform application that deserve more extended consideration. Do uniform enabling statutes that permit "local option" exemptions some liquor control and retail business holidays measures, for instance - "extend uniformly throughout the jurisdiction"? What about schemes that use planning boards in some parts of the province but committees of adjustment in others? What about site-specific provisions or exemptions enacted as regulations under statutes of general application? At what level of generality should we be conducting this inquiry?

The Quebec Court of Appeal considered some of these issues recently in Municipalite d'Oka c. Simon, [1999] 2 C.N.L.R. 205 [hereinafter Oka]. It concluded (ibid. at 221-22 (paras. 63-66)) that a municipal zoning ordinance met this standard of uniform application, despite prescribing different permissible uses for the lands in different geographic areas, because the scheme of the bylaw applied uniformly throughout the town, and because the ordinance was, in the court's view, an integral part of an orderly municipal framework for the deployment of municipal resources and services. 
The Supreme Court's second criterion is the one that needs closer examination. It requires attention to "the intention and effects of the enactment" as follows:

The law must not be "in relation to" one class of citizens in object and purpose. But the fact that a law may have graver consequences to one person than to another does not, on that account alone, make the law other than one of general application. There are few laws which have a uniform impact. The line is crossed, however, when an enactment, though in relation to another matter, by its effect, impairs the status or capacity of a particular group. The analogy may be made to a law which in its effect paralyzes the status and capacities of a federal company.... ${ }^{109}$

This passage implies that a measure or provision will be "in relation to" a particular class or group, and for that reason will not count as a law of general application, if it has the effect of impairing that group's status or capacity. Later on in the judgment, however, the Supreme Court goes on to say that "[i]t would have to be shown that the policy of the [relevant] Act was to impair the status and capacities of Indians." 10 Relying in part on this latter quotation, it subsequently concluded, in Dick, that mere demonstration of such an effect was not sufficient to disqualify a provision or statute from being a law of general application. "I" "Effect and intent," the court said there,

are both relevant. Effect can evidence intent. But in order to determine whether a law is not one of general application, the intent, purpose or policy of the legislation can certainly not be ignored: they form an essential ingredient of a law which discriminates between various classes of persons, as opposed to a law of general application. ${ }^{112}$

The fact, therefore, that a measure impairs some group's capacity or status will deny it the character of general application if and only if it suffices in all the circumstances to sustain an inference that the measure was enacted to have that effect.

To understand what this means in practice, we need to remember the kinds of provincial laws to which s. 88, as a whole, pertains. Section 88 exists to give federal effect to those valid provincial measures that could not, as such, apply to Indians. It does not govern the application of valid provincial laws that apply to Indians of their own force, and it cannot give effect to provincial laws that are simply invalid. The only provincial laws, then, even eligible for consideration for federal incorporation pursuant to s. 88 are those whose primary business is not to regulate s. 91(24) lands or Indians (or any other matter within exclusive federal authority) but whose provisions, applied full strength, would nonetheless have the effect of doing so. ${ }^{113}$ These are the laws the only laws - to which s. 88's "general application" requirement has any relevance. For such laws, that requirement serves as one additional eligibility barrier to federal incorporation. The present task is to understand just how that barrier functions.

\footnotetext{
(16) Kruger \& Manuel, supra note 36 at 110.

Ibid. at 112 [emphasis added].

See Dick, supra note 39 , especially at 325-26.

Ibid. at 323-24.

See supra notes $36-56,76-80$ and accompanying text.
} 
There are, in my view, two kinds of provincial laws that might fail the Supreme Court's second - impairment - test for laws of general application: those that display an intention to impair the status or capacity of Indians and those that display an intention to impair the status or capacity of some other identifiable group, which may or may not include any Indians. ${ }^{1 / 4}$ Let us consider them both, but in reverse order.

The impairment test will not affect the application of provincial laws of the second kind - those designed to impair the status or capacities of left-handed people, itinerant salesfolk, or companies incorporated in New Brunswick, for instance - because such laws will almost always apply routinely to Indians of their own force; other things equal, they will rarely, if ever, have the effect of regulating matters integral to federal authority over s. 91(24) lands or Indians. For present purposes, therefore, it rarely matters whether we call such measures "laws of general application" because s. 88 has no impact on them.

The same is true, though for different reasons, of the other kind of provincial measures that fail the Supreme Court's impairment test: those that display an intention to impair Indians' status or capacity. Whether or not such measures were "laws of general application," s. 88 could not give federal effect to them, because they are simply invalid: altogether beyond provincial authority. ${ }^{115}$ Under Canada's constitution, only the federal order of government may set about to impair the status or capacity of Indians. ${ }^{116}$

This means that the impairment test of general application, understood as a test of provincial intention to impair, is left with no meaningful work to do within the context of s. 88. The only laws it can exclude are laws to which, for other reasons, s. 88 would not apply in any event. Subject to its other exceptions, therefore, s. 88, so understood, incorporates into federal law all valid provincial measures that cannot apply to Indians as long as their application is uniform throughout the province.

To some, this result may seem good enough reason to reconsider adopting an impairment test based on effects. Such a test would disqualify from "general application," and therefore from incorporation pursuant to s. 88, any provincial law whose effect was to impair the status or capacity of Indians or of any other identifiable group.

The impairment test, as formulated, asks only whether the relevant measure "impairs the status or capacity of a particular group," not which group it is whose status or capacity may be at risk: see quotation supra note 109 . Strictly speaking, therefore, it makes no difference - at least for the purpose of giving effect to this requirement - whether or not the "particular group" is (or even includes any) Indians. Although Indians, or some subgroup of them, will almost always be the group most relevant for purposes of the s. 88 inquiry, the test itself seems designed to have (if you will forgive me) more general application. See, e.g., Oka, supra note 107 at 219-21 (paras. 56-61) (even apart from s. 88, provincial and municipal laws must be of general application, in this sense, to apply to Indian lands or to federal public property).

116 See supra notes $43-50$ and accompanying text. 
An effects-based approach, however, has disadvantages opposite to those we found in the test based on intent. The problem with the intent-based test was that it would screen out no laws that were otherwise eligible for incorporation pursuant to s. 88; the problem with an effects-based test is that very few, if any, relevant provincial laws could pass it. On an effects-based test for laws of general application, the only laws that s. 88 could incorporate would be those that, on their own, somehow managed to have the effect of regulating or disposing of matters integral to "Indianness" without impairing Indians' status or capacities. ${ }^{117}$ Although the courts have recognized, and applied in other contexts, a distinction between these two notions, ${ }^{118}$ it is not easy to think of examples that could illustrate it from among the matters within exclusive federal authority under s. 91(24). (And in Dick, for example, the Supreme Court all but conflated them.) $)^{119}$ And even if we succeeded, s. 88, for all its sound and fury, would amount, in the end, to not very much. It is hard to believe that Parliament, when it enacted s. 88, intended it to govern only so narrow (and, frankly, arbitrary) a selection of provincial laws.

Reasonable people can differ about which of these solutions - making the words "laws of general application" all but redundant or making s. 88 as a whole almost inapplicable - is less objectionable and makes better doctrinal sense of s. 88. I wish I had another solution to offer to this predicament. To me, it illustrates afresh the profound conceptual confusion that lies at the very nucleus of s. 88 .

All we can say we have learned from this phrase, therefore, is that s. 88 does not govern federal legislation and that it does not give federal effect to provincial laws that do not apply uniformly throughout the territorial jurisdiction of their enacting legislatures.

\section{D. “... ARe Applicable to and in Respect of Indians in the Province ..."}

This phrase prescribes the entities to be governed by the provincial procedures and standards that $\mathbf{s .} 88$ incorporates. It requires that we consider two extremely important issues: which Indians are to be subject to the incorporated measures and whether the measures incorporated can include those that govern the use, possession, occupation, or disposition of land.

117 Even laws in this narrow class, strictly speaking, would be ineligible for incorporation pursuant to s. 88 if they impaired any other groups' status or capacity. See supra note 114 and accompanying text.

I have assumed that [the B.C. Wildlife Act's] application to the appellant would have the effect of regulating the latter qua Indian. However, it has not been demonstrated, in my view, that this particular impact has been intended by the provincial legislator. While it is assumed that the Wildlife Act impairs the status or capacity of appellant, it has not been established that the legislative policy of the Wildlife Act singles out Indians for special treatment or discriminates against them in any way:

Dick, supra note 39 at 325-26 [emphasis added]. 


\section{WHICH INDIANS?}

The first of these questions, though important, is fairly easily answered. "Indian" is a term defined within the Indian $A c t,{ }^{120}$ so the only Indians to whom incorporated measures apply are those that satisfy the statutory definition. The cohort defined by the statute ("statutory Indians") is not identical to the group ("s. 91(24) Indians") whose members, as such, are subject exclusively to federal authority pursuant to s. 91(24) of the Constitution Act, 1867. We know, for example, that Inuit cannot be statutory Indians ${ }^{121}$ even though they are, indisputably, s. 91(24) Indians. ${ }^{122}$ Section 88, therefore, by its own terms, has no impact on the Inuit or on any other s. 91(24) Indians - or others ${ }^{123}$ - who do not qualify as statutory Indians. ${ }^{124}$ To those in that group, provincial measures either apply of their own force or not at all. ${ }^{125}$ It does, on the other hand, apply incorporated provincial measures to all statutory Indians whether or not they are also s. 91(24) Indians. ${ }^{126}$

\section{Provincial laws about land}

The more difficult issue the current phrase poses - especially when read together with the one just preceding it - is what impact, if any, s. 88 has on the application of provincial measures to interests in, and uses of, reserves and other "Lands reserved for the Indians" ("s. 91(24) lands"). On the one hand, s. 88's text provides that "all laws of general application ... are applicable to and in respect of Indians"; nothing it says excludes provincial laws that happen to deal with land uses or interests. On the other hand, those same words say that "all laws of general application ... are applicable to and in respect of Indians in the province"; they say nothing comparably specific to suggest that such laws are also to govern Indian lands. And therein lies the controversy.

According to s. 2(1) of the Indian Act, "'Indian' means a person who pursuant to this Act is registered as an Indian or is entitled to be registered as an Indian"; the registration entitlement rules appear in the Act as ss. 5-7. In addition, s. 4.1 of the Indian Act deems "any person whose name is entered in a Band List and who is entitled to have it entered therein" to be an "Indian" for many (but not all) purposes under the Act. Section 88 is one of several provisions to which this extended definition applies. See Indian $A c t$, ss. 8-14.3 for the rules prescribing band list entitlements.

"A reference in this Act to an Indian does not include any person of the race of aborigines commonly referred to as Inuit": Indian Act, s. 4(1).

It will not apply to Métis, for example, whether or not Métis are s. 91(24) Indians, unless and except where they happen to meet the statutory requirements for registration or for band list enrollment.

124 For a similar view, see K. McNeil, "Aboriginal Title and Section 88 of the Indian Act" 1999 [unpublished] [hereinafter McNeil, "Section 88"] (forthcoming U.B.C. L. Rev.) at 41.

125 See, e.g., R. v. Alphonse, [1993] 5 W.W.R. 401 (B.C.C.A.) [hereinafter Alphonse] at 420 (paras. 54-56); K. McNeil, "Aboriginal Title and the Division of Powers: Rethinking Federal and Provincial Jurisdiction" (1998) 61 Sask. L. Rev. 431 [hereinafter McNeil, "Rethinking Jurisdiction"] at $447, \mathrm{n} .75$. 


\section{a. Why It Matters}

It is important to understand from the outset why, and to what extent, it matters what we say about this. It matters principally because a great many provincial measures will have no application at all on s. 91(24) lands unless s. 88 gives them effect as federal law. It is increasingly clear how little independent capacity the provinces have to regulate matters related to such lands. We already know, for example, that the provinces have no power to regulate the occupation, ${ }^{127}$ possession, ${ }^{128}$ or use of $\mathrm{s}$. 91(24) lands or the nature or disposition of the interests in them. ${ }^{129}$ There is, in my view, some reason to doubt even that the provinces may authorize their own officials to enter such lands without consent to enforce provincial laws that do apply there. If s. 88 does not give federal effect to provincial measures relating to land or to its use, these incapacities stand.

In a wide range of contemporary circumstances, of course, none of this makes any difference at all. Often there is another reason why provincial schemes (of general application) related to land will not govern s. 91(24) lands. ${ }^{130}$ Elsewhere in the Indian $A c t$, and in certain regulations and band council bylaws passed pursuant to it, federal authorities have themselves made extensive provision for the use, possession, and occupation of lands on Indian reserves and for the regulation and disposition of the interests in those lands. ${ }^{131}$ Because of the phrasing at the very end of $s .88,{ }^{132}$ these

See, e.g., Paul v. Paul, [1986] I S.C.R. 306 [hereinafter Paul] at 311.

Derrickson, supra note 52 at 296; Canadian Pacific v. Paul, [1988] 2 S.C.R. 654 [hereinafter CP v. Paul] at 673.

Derrickson, ibid. at 295, quoting with approval K.M. Lysyk, "Constitutional Developments Relating to Indians and Indian Lands: an Overview" [1978] L.S.U.C. Special Lectures 201 at 227, n. 49; Stoney Creek Indian Band v. British Columbia, [1999] I C.N.L.R. 192 (B.C.S.C.) at 211-13 (paras. 51-55) [hereinafter Stoney Creek] (reserve lands), set aside on other grounds (1999), 179 D.L.R. (4th) 57 (B.C.C.A.) [hereinafter Stoney Creek (C.A.)]. See also Delgamuukw, supra note 48 at 1083 (para. 117), 1119 (para. 178); Chippewas of Sarnia, supra note 68 at 146-47 (para. 477) (Aboriginal title lands). All these matters have been held to be integral to - part of the "core" of - exclusive federal authority over s. 91(24) lands. See generally "Section 35 Rights," supra note 43 at 197-99; Bankes, supra note 43 at 337-45, especially at 344 . This has been held to be so even where non-Aboriginal persons have lawful possessory interests in s. 91(24) lands: see, e.g., Surrey v. Peace Arch Enterprises (1970), 74 W.W.R. 380 (B.C.C.A.) [hereinafter Peace Arch], especially at 383,386 and the other cases cited at infra note 142 . But see Oka, supra note 107 at 222-25 (paras. 68-73) (only possession and Indian use of s. 91(24) lands is outside the reach of provincial legislative authority). Compare Tyler, supra note 54 at 4-9.

Certain site-specific provincial measures, for example, may well fail to qualify as "laws of general application" for purposes of incorporation pursuant to $\mathrm{s.} \mathrm{88,} \mathrm{because} \mathrm{they} \mathrm{do} \mathrm{not} \mathrm{"extend} \mathrm{uniformly}$ throughout the territory": see supra notes 105-108 and accompanying text. Alternatively, some federal provision, outside the Indian Act, may displace, and preclude the application of, a provincial measure even if s. 88 would otherwise give it effect: supra notes 92-101 and accompanying text.

See, e.g., Indian $A c t$, ss. 18-31, 35-44, 50, 53-60. See also ss. 73(1)(i)-(m), which authorize the Governor-in-Council to make regulations, and ss. $81(1)(\mathrm{g})-(\mathrm{i}),(\mathrm{p})-(\mathrm{p} .1)$, which authorize band councils to enact bylaws, concerning a substantial number of land-related issues. For a much more extensive catalogue of such provisions, see McNeil, "Section 88," supra note 124 at 32-40.

"... except to the extent that such laws are inconsistent with this Act or any order, rule, regulation or by-law made thereunder, and except to the extent that such laws make provision for any matter for which provision is made by or under this Act." For more detailed discussion of these phrases, 
arrangements take precedence over incorporated provincial measures not only where there is actual conflict, but wherever there is any overlap in subject matter. As long as they remain in force, these federal arrangements will continue to govern these matters to the exclusion of any incorporated provincial laws whether or not s. 88 is understood, in the abstract, to give federal effect to provincial measures that regulate land. ${ }^{133}$ Where this is so, it will matter little what we say about that larger issue.

This realization is, of course, very important: so important that it may tempt us to think we can side-step altogether the broader question of s. 88's impact on provincial land regimes. In my view, any such confidence would be misplaced.

To begin with, it is a contingent fact that the Indian Act gives effect to provisions, regulations, and bylaws that govern the use, possession, occupation, and disposition of reserve lands. Any or all of those arrangements could disappear at any time, independent of s. 88; if they did, we could not determine what other mainstream arrangements, if any, would govern in their absence without having clarified s. 88's effect on provincial land laws.

In addition, even the present federal regime of Indian land regulation is not comprehensive. There is, for example, no current federal measure that clearly precludes provincial limitations legislation from applying on reserve and anchoring there outsiders' claims of adverse possession or other prescriptive rights. ${ }^{134}$ Whether such provisions really do apply on reserve, therefore, appears to depend almost entirely $y^{135}$ on what we say about their eligibility for incorporation pursuant to s. $88 .{ }^{136}$

Finally, and perhaps most important, the land-related provisions in the Indian Act and in its subordinate legislation pertain exclusively to the lands that the Indian Act has defined as "reserves." ${ }^{137}$ For present purposes, however, reserves are by no means the

see infra notes 193-215 and accompanying text.

III For a similar argument, to somewhat different effect, see McNeil, "Section 88," supra note 124 at $31-40$.

134 See, e.g., Stoney Creek, supra note 129, set aside on procedural grounds by Stoney Creek (C.A.), supra note 129.

135 Other federal laws incorporate, for limited purposes, provincial limitations legislation: see, e.g., Federal Court Act, R.S.C. 1985, c. F-7, s. 39(1) (applying provincial limitations provisions to proceedings brought in Federal Court); Crown Liability and Proceedings Act, R.S.C. 1985, c. C-50, as am. by S.C. 1990, c. 8, s. 32 (applying a province's laws about prescription and limitations to all proceedings by or against the federal Crown in respect of causes of action arising within that province).

136. This is so, again, because provincial limitations measures do not apply of their own force to $\mathrm{s}$. 91(24) lands: see, e.g., $C P$ v. Paul, supra note 128 at 673; R. v. Smith, [1981] 1 F.C. 346 (C.A.) [hereinafter Smith (F.C.A.)], rev'd. on other grounds [1983] I S.C.R. 554 [hereinafter Smith]; Stoney Creek, supra note 129 at 204 (para. 34), 217 (para. 66), set aside on procedural grounds by Stoney Creek (C.A.), supra note 129; Chippewas of Sarnia, supra note 68 at 146-48 (paras. 476-81). In Stoney Creek, ibid. at 202-205 (paras. 28-37) and Chippewas of Sarnia, ibid. at 149-52 (paras. 482-85), courts held that such measures also cannot apply pursuant to 5.88.

137 For that definition, see Indian Act, s. 2(1). This is true of the relevant Indian Act provisions and regulations because they speak expressly, and exclusively, of reserves. It is true of band council bylaws, whether or not their application is confined, in terms, to reserves, because band councils, as such, have no territorial jurisdiction off reserve. See, e.g., Lewis v. R., [1996] 1 S.C.R. 921 at 
only lands that matter. We have known for over a century that "the words actually used [in s. 91(24) of the Constitution Act, 1867] are, according to their natural meaning, sufficient to include all lands reserved, upon any terms or conditions, for Indian occupation,"138 not just those lands that qualify under the statute as "reserves." We now know, for instance, that s. 91(24) lands include "lands held pursuant to Aboriginal title,"139 whether or not such lands have ever been "set apart by Her Majesty for the use and benefit of a band." ${ }^{140}$ These lands too, of course, are beyond the reach of provincial land regulation, considered as such, ${ }^{141}$ as long as some Aboriginal possessory interest, even a mere reversionary interest, subsists in them. ${ }^{142}$ In the

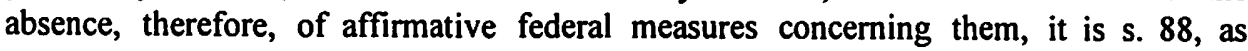
interpreted, that will determine what mainstream legal regime, if any, is going to govern the use, possession, occupation, or disposition of these lands. It will, to take just one example, determine what rights, if any, provincial laws related to matrimonial property disposition can confer on Aboriginal (or other) women residing off reserve on Aboriginal title lands. ${ }^{143}$

958-59 (paras. 76-80).

St. Catherine's Milling, supra note 61 at 59 [emphasis added]. See also Slattery, supra note 99 at 773; McNeil, "Section 88," supra note 124 at 42. See Delgamuukw, supra note 48 at 1116 (para. 174). See Indian Act, s. 2(1) ("reserve"). It is still unresolved whether there are any s. 91(24) lands that are neither reserve lands nor Aboriginal title lands. See, e.g., Oka, supra note 107.

See supra notes $127-29$ and accompanying text. It is important to realize, too, that once particular lands become, or are recognized as being, s. 91(24) lands, the provinces have no control whatever over whether or how long they shall remain so. As a matter of constitutional law, the provinces lack the power either to extinguish the Aboriginal interest in such lands (see CP v. Paul, supra note 128 at 673; Delgamuukw, supra note 48 at 1115-23 (paras. 172-83)) or to procure and accept the voluntary surrender of such interests: Delgamuukw, ibid. at 1117-18 (para. 175). Section 88 does nothing to equip them with either capacity: see Delgamuukw, ibid. at 1121-23 (paras. 18283). Other federal legislation equips the governments of Quebec and Ontario to obtain, at their own expense, surrenders of Aboriginal interests in the northern lands added to their territorial jurisdiction in 1912, but only with the approval of the federal Governor in Council: see The Ontario Boundaries Extension Act, 1912, S.C. 1912, c. 40, ss. 2(a)-(c); The Quebec Boundaries Extension Act, 1912, S.C. 1912, c. 45, ss. 2(c)-(e).

See, e.g., St. Ann's Shooting and Fishing Club v. R., [1950] S.C.R. 211 at 215-19; Peace Arch, supra note 129 at 386; Western Industrial Contractors v. Sarcee Developments (1979), 98 D.L.R. (3d) 424 (Alta. C.A.) at 426, Prowse J.A. (dissenting), at 434-36, Morrow J.A.; Reference re Stony Plain Indian Reserve No. 135 (1981), 130 D.L.R. (3d) 636 (Alta. C.A.) [hereinafter Re Stony Plain] at 650-53. Except in the Prairie provinces, where special arrangements still prevail pursuant to the NRTAs and the Constitution Act, 1930, Canada's constitutional authority over any such lands terminates forthwith upon the extinguishment or absolute surrender of the Aboriginal interest in them: see, e.g., Ontario Mining v. Seybold, [1903] A.C. 73 (P.C.) at 82; Smith, supra note 136 at $564,569,578$.

In Derrickson, supra note 52 at 299-303, and Paul, supra note 127 at 311, the Supreme Court held that such arrangements cannot operate on reserve because they conflict with the Indian ACt provisions (ss. 20-24) that govern allocation of possessory interests in specific reserve lands. The court, however, declined to determine whether $\mathbf{s .} 88$ would give effect to such arrangements in the absence of conflicting federal measures: see Derrickson, ibid. at 297-99. 
Where the s. 91(24) lands in issue are not reserve lands, therefore, a great deal is going to depend on whether s. 88 gives federal effect to provincial land regimes. ${ }^{144}$ If $\mathbf{s .} 88$ does not do so, no mainstream measures now in force will govern such matters in respect of such lands. ${ }^{145}$ Given the present uncertainty, especially in some parts of the country, about which lands are subject to valid claims of Aboriginal title, ${ }^{146}$ this situation poses some genuine risks of instability.

In at least some circumstances, therefore, it will matter profoundly whether $\mathrm{s} .88$ is understood to apply provincial land regimes to Indian lands. We now must return to consider that primary issue. Does s. 88 (subject only to its other exceptions) impose provincial land regulation on s. 91(24) lands or not?

Strictly speaking, this will be so only if s. 88 itself has any application to s. 91(24) lands that are not reserve lands. If it does not, then provincial land regimes will not apply to such lands whether or not s. 88 is properly understood to give federal effect to such regimes for other purposes.

It is, in my view, at least arguable that s. 88 has no application to s. 91(24) lands that are not reserves. The Indian Act as a whole concerns itself almost exclusively with property and activity located on reserve: see, e.g., supra note 137; the only exceptions I have found are s. 4(3), which extends the Act's provisions on estates and education to Indians who reside on federal or provincial Crown lands, and ss. 5-14.3, the rules for "status" and band membership, which have no territorial referent. If the territorial reach of the rest of the Act is confined to lands that meet the Act's definition of "reserve," it makes at least some sense to suppose that the same is true of s. 88.

This argument may well deserve further thought. My current inclination, however, is to reject it, principally for two reasons: First, although it is true that most of the Indian Act pertains exclusively to reserves and to on-reserve activity, this is so not because of some general provision in the Act that circumscribes its territorial reach, but because of a host of individual drafting decisions linking particular sections of the Act with reserves expressly. Section 88 is almost unique in containing no such reference. Such an omission, when viewed in the context of this overall drafting structure, encourages the inference that $s .88$ was meant to be an exception to this overall pattern and to apply more generally, according to its terms. Second, it is difficult to understand, from a policy standpoint, why Parliament, in prescribing the reach of $\mathrm{s}$. 88, would want to distinguish between reserves and other s. 91(24) lands. To begin with, it seems generally acknowledged that Indians living or working on lands that are not s. 91(24) lands (or federal public property: see Constitution Act, 1867, s. 91, para. 1A) are subject, other things equal, to provincial land regimes and that $s .88$ helps, as necessary, to make this so: see infra note 181 and the sources cited there. The effect in these circumstances of any such distinction would be for $\mathbf{s}$. 88 to facilitate the application of such regimes to Indians in respect of all lands except s. 91(24) lands that are not reserves. Such a result seems arbitrary and counterintuitive, especially given the well-established fact that the Aboriginal interest in reserve lands as such is qualitatively the same as that in s. 91(24) lands generally (see, e.g., Quebec (A.G.) v. Canada (A.G.), [1921] 1 A.C. 401 (P.C.) at 410-11; Guerin v. R, [1984] 2 S.C.R. 335 [hereinafter Guerin] at 379; Delgamuukw, supra note 48 at 1085-86 (paras. 120-121)), and that both are qualitatively different in some important respects from the interests of persons generally in other lands (see Delgamuukw, ibid. at 1081-83 (paras. 112-17), 1088-91 (paras. 125-32)). In the absence of some clear contrary legislative intention, this is a conclusion that it makes good sense to avoid. In principle, of course, such lands continue to be subject to the common law. In recent years, however, the Supreme Court has shown increasing reluctance to rely on common law notions in dealing with lands that are subject to subsisting Aboriginal interests. See, e.g., St. Mary's Indian Band v. Cranbrook (City of), [1997] 2 S.C.R. 657 at 666-68 (paras. 14-16). Aboriginal title; instead, it sent the issue back for retrial (ibid. at 1123 (para. 184)). 


\section{b. Excluding Provincial Land Laws}

Supreme Court of Canada judgments have sometimes commented on this issue, but, in all probability, have not yet pronounced decisively upon it. ${ }^{147}$ Almost every lower court $^{148}$ and commentator ${ }^{149}$ addressing the issue, however, has concluded that s. 88 does not give federal effect to provincial legislation as applied to s. 91(24) lands. Frequently, those espousing this view have relied on nothing more substantial than the fact that s. 88 makes no mention of land. ${ }^{150}$ That fact alone surely cannot be sufficient reason to withhold full effect from a statutory phrase that begins with the words "all laws...." Section 88 makes no mention of unsurrendered hunting rights, either, but it has been held decisively to apply provincial hunting laws to them in the absence of a treaty. ${ }^{151}$ There are, however, at least two other, more fully developed arguments sometimes offered in support of this view. I want to consider each of them in turn.

In Cardinal, supra note 36, Laskin J., dissenting on other grounds, concluded (at 727-28) that s. 88 "deals only with Indians, not with Reserves"; the majority did not consider the issue. And in Derrickson, supra note 52, the court reviewed (at 297-99) the arguments for the two positions, but left the question open.

Most recently, in Delgamuukw, supra note 48, a case in which the present issue did not arise for decision, the court observed (at 1122 (para. 182)) that "s. 88 extends the effect of provincial laws of general application which cannot apply to Indians and Indian lands because they touch on the Indianness at the core of s. 91(24)." It is possible that future courts will treat this observation as having decided that $\mathbf{s .} 88$ does indeed incorporate and give federal effect to provincial land law. At present, however, it seems premature to regard it as determinative. (See, for similar assessments, Stoney Creek, supra note 129 at 204-205 (para. 35); Chippewas of Sarnia, supra note 68 at $151-52$ (para. 494); McNeil, "Rethinking Jurisdiction," supra note 125 at 447; Bankes, supra note 43 at 333-35; McNeil, "Section 88," supra note 124 at 4-5. For one thing, the Delgamuukw court took no time - and had no reason there to take time - to consider the earlier jurisprudence and commentary on this issue, almost all of which has reached the opposite conclusion: see infra notes 148-49 and accompanying text. For another, there is no evidence that the Delgamuukw court considered the troubling practical consequences (discussed infra at notes 183-90 and accompanying text) that would result from adopting that conclusion. See, e.g., R. v. Johns (1962), 39 W.W.R. 49 (Sask. C.A.); R. v. Isaac (1975), 13 N.S.R. (2d) 460 (C.A.); Millbrook Indian Band v. Northern Counties Residential Tenancies Board (1978), 84 D.L.R. (3d) 175 (N.S.S.C.), aff d. without reference to the point (1978), 93 D.L.R. (3d) 230 (N.S.C.A.); Palm Dairies v. R. (1978), 91 D.L.R. (3d) 665 (F.C.T.D.); Re Park Mobile Home Sales and Le Greely (1978), 85 D.L.R. (3d) 618 (B.C.C.A.); Smith (F.C.A.), supra note 136, rev'd. without reference to the point by Smith, supra note 136; Re Stony Plain, supra note 142; $R$. v. Martin (12 August 1985), (Ont. Dist. Ct.) [unreported] [hereinafter Martin]; $R$. v. Fiddler, [1993] 3 W.W.R. 594 (Sask. Q.B.); Stoney Creek, ibid; Chippewas of Sarnia, ibid. at $151-52$ (paras. $492-$ 94).

Sec, e.g., Lysyk, supra note 57 especially at 518; P. Hughes, "Indians and Lands Reserved for the Indians: Off-Limits to the Provinces?" (1983) 21 Osgoode Hall L.J. 82 at 99; Slattery, supra note 99 at 779-81; D. Sanders, "The Constitution, the Provinces, and Aboriginal Peoples" in Governments in Conflict?, supra note 23, 151 at 156, n. 14 (at 287); Little Bear, supra note 23 at 439-41; Reiter, supra note 75 at 201; McNeil, "Rethinking Jurisdiction," supra note 125 at 439-41; D. Lambert (J.A.), "Van der Peet and Delgamuukw: Ten Unresolved Issues" (1998) 32 U.B.C. L. Rev. 249 at 266-67; McNeil, "Section 88," supra note 124 at 15-42. In a recent article, Kent McNeil, reviewing the decided cases, described this as "the main argument for not using the section to apply provincial laws relating to land on reserves": see McNeil, "Section 88," supra note 124 at 21.

1st See, e.g., Kruger \& Manuel, supra note 36 at 114-15; Dick, supra note 39 at 328 . Today, of course, this conclusion may well need reconsideration in light of s. 35(1) of the Constitution Act, 1982. 
The first of these arguments goes as follows:

Section 91(24) of the Constitution Act, 1867 gives Parliament jurisdiction over both subject-matters [viz., "Indians, and Lands reserved for the Indians"], and the Supreme Court had held that they are two distinct heads of power. It follows that $\mathbf{s .} 88$ does not referentially incorporate provincial laws that affect the possession and use of lands reserved for Indians. ${ }^{132}$

I confess that I have never understood this argument. Section 91(24) does indeed provide for these two different heads of federal power; ${ }^{153}$ my question concerns what that fact has to do with the task of construing s. 88 .

As a general rule, courts strongly resist addressing constitutional issues unless it is necessary for them to do so. ${ }^{154}$ When construing regular legislation, they do not concern themselves with the constitution, or use the heads of federal or provincial power as interpretive aids, unless there is occasion to doubt the constitutional pedigree - the validity or the constitutional applicability - of the statutory provisions before them. When they do undertake such inquiries, their practice, in division of powers cases especially, is to determine only those issues essential to dispose of the current matter. ${ }^{15 s}$ Because it almost never matters, for constitutional purposes, which specific head of power anchors valid legislation, ${ }^{156}$ courts very rarely commit themselves to such determinations. ${ }^{157}$

Section 88 is not a provision whose constitutional status turns on a differentiation between the federal powers over "Indians" and those over Indian lands. No one doubts

Slattery, supra note 99 at 779 (footnotes omitted). Compare Sanders, supra note 149 at 156, n. 14 (at 287); McNeil, "Rethinking Jurisdiction," supra note 125 at 440; Lambert, supra note 149 at 266-67; McNeil, "Section 88," supra note 124 at 26-27. In Sioney Creek, supra note 129, the Supreme Court of British Columbia described this (at 205 (para. 36)) as "a reasonable inference"; in Chippewas of Sarnia, supra note 68 at 151 (para. 492), Ontario's Superior Court of Justice expressly agreed.

iss See, e.g., Four B, supra note 36 at 1048-50; Lysyk, supra note 57 at 514-15, 541-42.

154 "Save in exceptional circumstances, it is not desirable to express an opinion on a question of law which it is not necessary to decide in order to dispose of the case at hand, especially when it is a constitutional question": Quebec (A.G.) v. Cumming, [1978] 2 S.C.R. 605 at 611 . See also, e.g., Skoke-Graham v. R., [1985] I S.C.R. 106 at 121-22; Ontario (A.G.) v. Regional Municipality of Peel, [1979] 2 S.C.R. 1134 at 1138.

15s See, e.g., Citizens Insurance Co. of Canada v. Parsons (1882), 7 App. Cas. 96 (P.C.) at 109; Proprietary Articles Trade Association v. Canada (A.G.), [1931] A.C. 310 (P.C.) at 316-17.

15. See, e.g., Hogg, supra note 51 at 347, n. 38. There are some exceptions. In deciding whether a given provincial or federal measure contravenes s. 125 of the Constitution Act, 1867 (intergovernmental tax immunities), for instance, courts need to decide whether the measure's validity depends entirely on the enacting legislature's taxation power. See, e.g., Reference re Exported Natural Gas Tax, [1982] I S.C.R. 1004 at 1074. Compare Bankes, supra note 43 at 32829, n. 61.

157 See, e.g., CN Transportation, supra note 61 at 255-56, Dickson J. (concurring). In that case, Dickson J. believed that the outcome of the appeal did turn on the head of power to which the court attributed the relevant federal legislation. The majority disagreed and so did not consider the alternative heads of power: see ibid. at 244 . 
Parliament's legislative authority to do what S. 88 , broadly speaking, does: ${ }^{158}$ incorporate certain provincial laws for the purpose of applying them to Indians. No one doubts, either, that Parliament also has a constitutional mandate to apply the incorporated laws to section $91(24)$ lands. ${ }^{199}$ The only issue in dispute is whether s. 88 was enacted to do the latter as well as the former. In these circumstances, there is no good reason, at least on generally accepted constitutional principles, for us to pay any special attention to the bifurcated structure of s. 91(24) in resolving what is, after all, a fairly typical issue of statutory interpretation. And nothing we know of s. 88's legislative history suggests that Parliament, in the course of enacting that provision, took unusual - or, indeed, any — interest in s. 91(24)'s cartography. ${ }^{160}$

Unless there is something exceptional about s. 88, it seems artificial to circumscribe its application because of the way the constitution has individuated the heads of federal legislative authority. (No one would even consider suggesting, for instance, that the Criminal Code (Constitution Act, 1867, s. 91(27)) had no application to banks (s. 91(15)) or to railways (ss. 91(29), 92(10)(a)) because it does not mention them explicitly.) In a recent article, however, Kent McNeil has suggested that it may indeed be appropriate to regard s. 88 as exceptional. "It has to be kept in mind," he argues,

that what we are discussing here is, in effect, a very serious extension of provincial authority into exclusive federal jurisdiction by referential incorporation of both existing and future provincial laws. Given the impact of this on Indians as defined in the Indian Act, to whom the federal government has fiduciary obligations and constitutional responsibilities, one would expect Parliament to express itself clearly if it intended to authorize the intrusion of provincial laws into both heads of s. 91(24) power.

By mentioning only one, surely Parliament intended to exclude the other. ${ }^{161}$

This, in my view, is the kind of move one must make to render this line of argument plausible. Even in this more considered form, however, I find it unconvincing. First, although it is common (and appropriate) today to characterize the federal Crown's relationship with Aboriginal peoples as fiduciary, there is good reason to doubt that the federal legislators themselves understood the situation in those terms in 1951 when they

There have been doubts about the scope of federal power to engage in "anticipatory" incorporation by reference of provincial legislation, but the Supreme Court of Canada concluded, rightly or wrongly, in Dick, supra note 39 (at 328), that its use, in s. 88 at least, was permissible. See supra note 57 and accompanying text. And one important reason why the Supreme Court concluded that s. 88 was incorporative and not declaratory was that Parliament lacked the power to prescribe, in legislation, the terms on which its own laws were to take precedence over free-standing provincial laws that are also valid and applicable. See supra note 54 and accompanying text.

Subject today, of course, to s. 35 of the Constitution Act, 1982. See, e.g., Sparrow, supra note 75 at $1109-10$.

Indeed, I have seen no evidence that Parliament or Cabinet ever considered either the impact $\mathbf{s}$. 87 (as it then was) might have on s. 91(24) lands or the relationship between that provision and s. 91(24) generally. See supra notes 19-34 and accompanying text. And even if they had considered the issue at the time, it is far from obvious that they would have recognized as clearly as we do today that "Indians" and "Lands reserved for the Indians" are distinct sources of federal legislative authority.

161 McNeil, "Section 88," supra note 124 at 26-27 [emphasis in original; footnotes omitted]. Brian Slattery has also invoked, in this context, the federal fiduciary obligation: see Slattery, supra note 99 at $779-80$. 
enacted (what we now call) s. 88. It was only in 1984, the year of the Guerin decision, ${ }^{162}$ that Canada's relationship to the Indians was recognized authoritatively to be, and was labelled, fiduciary. It seems improbable, therefore, to suppose, even hypothetically, that Parliament took account of a federal fiduciary obligation when it formed the intention to enact s. $88 . .^{163}$ Second, s. 88, and federal referential incorporation statutes generally, do not, as I understand them, "exten[d] ... provincial authority into exclusive federal jurisdiction." Such legislative measures do not, and could not, increase the independent capacity of the provinces themselves to legislate about, or apply their own laws to, s. 91(24) Indians or lands; ${ }^{164}$ instead, they adopt, as federal law, certain provincial measures that happen, for the time being, to suit the legislative purposes of the federal government. ${ }^{165}$ From a jurisdictional standpoint, $\mathrm{S}$. 88 is no different in kind from a series of federal enactments duplicating in statutes aimed expressly at Indians (and/or s. 91(24) lands) the relevant provincial measures individually; it is simply a technological shortcut available to achieve that same result. One need not on this account, therefore, invoke special constitutional considerations in construing it.

There is, however, another, separate argument in support of the view that $\mathrm{s} .88$ does not give federal effect to provincial laws about land. According to that argument, this view of $s .88$

is supported by the well-established rule that statutes affecting Aboriginal peoples should be generously and liberally construed, and any ambiguities resolved in their favour. If it contains ambiguity, s. 88 should therefore be interpreted so that referential incorporation extends only to provincial laws of general application that affect Indians, not Indian lands. ${ }^{\text {to }}$

This argument, unlike the earlier one, has impeccable doctrinal foundations; it has long been clear that statutory - and constitutional - provisions are, in cases of doubt, to be construed in the manner most favourable to the Indians. ${ }^{167}$ I am not sure,

See Guerin, supra note 144.

It could not, at that time, have had regard, either, for the constitutional obligations now identified by s. 35(1) of the Constitution Act, 1982. And no enumerated head of federal authority would, on its own, have prompted Parliament or the federal government to assume that Canada had "constitutional responsibilities" to Aboriginal peoples: see, e.g., Regional Municipality of Peel v. R., [1992] 3 S.C.R. 762 at 791 ("the power to legislate does not give rise to an obligation to legisiate"). "Parliament can no more give away federal constitutional powers than a province can usurp them": McEvoy v. New Brunswick (A.G.), [1983] I S.C.R. 704 at 720. See also, e.g., Nova Scotia (A.G.) v. Canada (A.G.) (Nova Scotia Interdelegation), [1951] S.C.R. 31 at 34, 54, 58.

See supra notes 39-56 and accompanying text.

McNeil, "Rethinking Jurisdiction," supra note 125 at 440. Compare Slattery, supra note 99 at 779 80, expressly adopted in Chippewas of Sarnia, supra note 68 at 151 (para. 492); McNeil, "Section 88," supra note 124 at 27-28. See also Bankes, supra note 43 at 329 , which emphasizes the importance of this consideration in resolving the present controversy.

See, e.g., R. v. Sutherland, [1980] 2 S.C.R. 451 at 461; Nowegijick v. R., [1983] 1 S.C.R. 29 at 36; Simon, supra note 48 at 402; Sparrow, supra note 75 at 1107 ; Mitchell, supra note 56 at 142 43. Mitchell, however, does contain an important cautionary note. According to La Forest J., who wrote for the majority on the issue (ibid. at 143):

I do not accept that this salutary rule that statutory ambiguities must be resolved in favour of the Indians implies automatic acceptance of a given construction simply because it may be expected that the Indians would favour it over any other competing interpretation. It is 
though, that we can so confidently assume, at least without some further inquiry, that it would always or routinely be to the Indians' benefit for their lands not to be governed by land regulation measures enacted, in the first instance, provincially. ${ }^{168}$ As we saw in some detail above, the only provincial land measures that s. 88 could incorporate would be those that filled gaps unaddressed altogether by other Indian Act provisions, regulations, or bylaws, or by other federal legislation; at the same time, in some circumstances, no mainstream law would govern the use, occupation, or disposition of s. 91(24) lands if s. 88 were held not to give federal effect to any land measures enacted provincially. ${ }^{169}$ Finally, the 1982 constitutional amendments now ensure that no incorporated provincial measures can operate to the detriment of existing Aboriginal rights - including Aboriginal title and any Aboriginal rights of selfgovernment - unless, at a minimum, the interference with such rights can be justified. ${ }^{170}$ In my view, these considerations invite us to think harder about the convenient assumption that Indians would benefit if no incorporated provincial laws applied to s. 91(24) lands. And if, as one court has suggested, ${ }^{171}$ the question of benefit is an issue for case-by-case determination, then this interpretive principle may not help very much in construing such a provision as s. 88, which entertains for incorporation (beneficial or not) either all the provincial land measures of general application or none of them. For the time being, therefore, it seems prudent not to treat this line of argument as decisive. ${ }^{172}$

\section{c. Including Provincial Land Laws}

What, then, of the alternative: the suggestion that the words "all laws" in s. 88 really mean all laws? On this broader view, $\mathbf{5} .88$ gives federal effect to all provincial

also necessary to reconcile any given interpretation with the policies the Act seeks to promote.

There is reason to suspect, for example, that at least some Aboriginal women would regret not being able to draw on provincial regimes for the disposition of matrimonial property if such regimes had no application on lands that were subject to Aboriginal title.

See supra notes 130-46 and accompanying text.

See Constitution Act, 1982, s. 35(1); Sparrow, supra note 75 at 1109-10.

There is still dispute about how the justification regime imported into s. $35(1)$ interacts with s. 88 and with the provincial measures that $\mathrm{s} .88$ incorporates. Two provincial courts of appeal have suggested that s. 88 itself needs no justification under s. 35(1), because it does nothing more than facilitate the application of the provincial measures that it incorporates: see Alphonse, supra note 125 at $421-23$ (paras. 62-65); R. v. Dick, [1993] 5 W.W.R. 446 (B.C.C.A.) at 453 (paras. 17-18); R. v. Sundown, [1997] 8 W.W.R. 379 (Sask. C.A.) at 400 (para. 61), affd. without reference to the point by Sundown, supra note 68 . Compare Bankes, supra note 43 at $320, n .12,334, n .84$. My own view, defended at length elsewhere, is that $\mathbf{s .} 88$ itself stands in need of justification, and that, under current standards, its operation cannot be justified when it gives federal effect to provincial measures that interfere with the exercise of Aboriginal rights: see "Section 35 Rights," supra note 43 at 226-33 and infra note 218. For a similar view, see McNeil, "Section 88," supra note 124 at 5-15. See also B. Slattery, "First Nations and the Constitution: A Question of Trust" (1992) 71 Can. Bar Rev. 261 at 285-86 (s. 88 "of doubtful constitutional validity," at least insofar as it restricts the exercise of Aboriginal rights of sclf-government).

See Alphonse, ibid. at 421 (para. 61): "Such incorporation [pursuant to s. 88] may give to Indians benefits extended by provincial legislation; or it may work to regulate, and occasionally interfere with Aboriginal rights."

But see infra notes 191-92 and accompanying text. 
measures otherwise eligible for incorporation, whether or not their own effect is to regulate or to dispose of land. This approach has fewer champions than the opposite view, ${ }^{173}$ but has received some academic ${ }^{174}$ and judicial ${ }^{175}$ support. Its best known formulation appears in the Derrickson decision, where the Supreme Court summarized, without accepting or rejecting, the submission made on behalf of the Attorney General of Ontario:

Pursuant to its legislative authority under s. 91(24) of the Constitution Act, 1867, Parliament has enacted, in $\mathbf{s .} 88$ of the Indian Act, law concerning the exposure of Indians to "all laws of general application from time to time in force in any province." It makes no difference whether those laws are in relation to lands or some other class of subjects. In either event, they are applicable to Indians subject to the limits prescribed in the section. There is no reason to import into the construction of the words in $\mathbf{5} .88$ the fact that Parliament has, pursuant to s. 91(24), not one but two subjects within its legislative authority. ${ }^{176}$

Considered in the context of s. 88 as a whole, this approach has some plausibility. The essence of the provision, as drafted, is that all (provincial) laws of general application are to apply to Indians unless (and except where) excluded by one or more of the several exceptions it enumerates. Those exceptions themselves are unusually numerous and detailed. The conventional interpretive inference ${ }^{177}$ from the number and specificity of the exceptions set out expressly ${ }^{178}$ would be that Parliament took special care to indicate with precision the features and circumstances that were to preclude some such laws from applying. This inference invites the conclusion that Parliament would have said so expressly if it had meant $\mathrm{s}$. 88 to preclude the incorporation of provincial land laws as such. If that had been the intention, it is much harder to understand why it would have chosen, in the midst of such a meticulous

See supra notes $148-49$ and accompanying text.

See P. Monahan \& A. Petter, "Developments in Constitutional Law: The 1985-1986 Term" (1987) 9 Sup. Ct. L. Rev. 69 at 169-70. See also Bankes, supra note 43 at 328-29, 333, 335, which reviews the controversy but takes no firm position about which view is preferable.

See, e.g., Delgamuukw v. R., [1993] 5 W.W.R. 97 (B.C.C.A.) [hereinafter Delgamuukw (C.A.)] at 172 (paras. 256-57) ("provincial land and resource laws affecting Aboriginal rights may be given force as federal law through the operation of s. 88 of the Indian Act") and, arguably, Delgamuukw, supra note 48 at 1122 (para. 182) ("s. 88 extends the effect of provincial laws of general application which cannot apply to Indians and Indian lands because they touch on the Indianness at the core of s. 91(24)"). But see supra note 147. For criticism of Delgamuukw (C.A.) on this issue, see McNeil, "Rethinking Jurisdiction," supra note 125 at $439-41$.

See also Boyer v. Canada, [1986] 2 F.C. 393 (C.A.), where the court notes in passing (at 404), in respect of reserve land, that "its use will, of course, always remain subject to provincial laws of general application." Given that federal authority over land use on reserve is exclusive (see supra notes 127-29 and accompanying text), one must conclude that such laws could apply only pursuant to s. 88. But the court in Boyer does not draw that conclusion expressly - or, indeed, even have occasion to mention s. 88 - and does not mention any other authorities on the issue. Derrickson, supra note 52 at 299 [emphasis in original].

Again, we have no evidence that Parliament ever actually considered s. 88 in these terms. All we have is the minister's view that "we have every form of gratification in there" to protect Aboriginal peoples' hunting and fishing rights. See Special Committee proceedings, supra note 20 at 167-68 (23 April 1951).

Especially in the absence of a "basket" clause such as "for greater certainty." 
itemization of exclusions, to leave this one exception - a broad and important one unstated. ${ }^{179}$

The challenge facing this approach is to deal sensibly with the fact that $\mathbf{s} .88$ says nothing about s. 91(24) lands: it specifies only that such laws are to apply to "Indians." One possible answer to this challenge is the one that British Columbia courts have given in respect of federal Crown land:

All legislation concerns itself with the rights and duties of persons, some with respect to rights and duties which arise out of the ownership, possession and use of land. It is people who have rights and duties, not land. If the land in question is federal Crown land, provincial or municipal legislation insofar as it purports to affect the rights and duties of persons in respect thereto is ineffective. ${ }^{\text {Ixo }}$

By parity of reasoning, one might well treat 5.88 as incorporating and applying to "Indians" all (eligible) provincial laws that affect rights and duties concerning land. ${ }^{181}$ It sometimes makes sense, when working through difficult s. 91(24) issues, to take direction from the decided cases concerning federal public property. ${ }^{182}$

On closer inspection, however, this approach has implications that are at once incongruous and deeply troubling.

Consider. When s. 88 operates on provincial laws that are unrelated to land, its effect is to bring statutory Indians under much the same set of legal standards as everyone

Compare Bankes, supra note 43 at $328-29$, n. 61.

Delta v. Aztec Aviation Group (1985), 28 M.P.L.R. 215 (B.C.S.C.) at 217-18, quoted with approval in Canadian Occidental Petroleum v. North Vancouver (District off (1986), 13 B.C.L.R. (2d) 34 (C.A.) at 47-48. Compare Greater Toronto Airports Authority v. Mississauga (City of) (1999), 43 O.R. (3d) 9 (G.D.) at 21-22.

Brian Slattery, who argues that s. 88 does not incorporate provincial land law, has acknowledged that this form of argument "seems plausible as far as it goes. Thus, lands held by Indians as ordinary citizens are subject to the general laws of the province, so they must conform for example to local building and health requirements": see Slattery, supra note 99 at 780 . "But it does not follow," he adds (ibid. at 780-81),

that $\mathbf{5 .} 88$ makes provincial laws applicable to the special category of lands reserved for Indians. That conclusion would follow only if such lands did not constitute a distinct constitutional subject-matter, but were simply subsumed under "Indians." As it is, Parliament's power to legislate for Indian lands does not flow from its jurisdiction over Indians. So Parliament's decision to make provincial laws of general application applicable to Indians leaves the subject-matter of Indian lands untouched.

See also McNeil, "Section 88," supra note 124 at 25-26, n. 80.

I can only repeat what I said before: statutory interpretation decisions almost never turn on the way the framers of our constitution happened to individuate the heads of federal and provincial power. (See supra notes 154-64 and accompanying text.) Again, the federal government's authority over banks and banking (Constitution $A c t$, 1867, s. 91(15)) "constitute[s] a distinct constitutional subject-matter" separate from its authority to control crime (s. 91(27)) or to raise money by taxation (s. 91(3)); it is fair to say, therefore, that legislation enacted under those heads "leaves the subject-matter of [banks and banking] untouched." All the same, I doubt that very many people would rush to conclude that the Criminal Code or the Income Tax Act has, for that reason, no application to banks. 
else: to put them in essentially the same position as non-Indians. ${ }^{183}$ This is so because those same standards already apply to everyone else (except s. 91(24) Indians) as valid and applicable provincial law. Like it or not, this seems consistent with what little we know of the federal policy behind s. $88 .^{184}$

Insofar as it operates on provincial laws about land, however, s. 88's effect is to do precisely the opposite. Unlike other provincial laws of general application, which apply, as such, to everyone else in the jurisdiction, provincial land laws, on their own, apply to no one - create and dispose of no rights or interests - as regards s. 91(24) lands. The federal authority over such lands, rights and interests is exclusive, no matter to whom those rights and interests happen to belong. ${ }^{185}$ The result, therefore, of including provincial land laws within s. 88's reach is to make such laws, on such lands, apply exclusively to statutory Indians. ${ }^{186}$ No one has ever suggested that s. 88 makes anything apply to anyone else. Instead of including statutory Indians within a general provincial regime of land regulation, in other words, s. 88, so understood, targets such a regime at them uniquely and does so on the very lands to which, as peoples, they have the closest traditional and practical connection.

To my intuition, the consequences of such an approach are perverse. ${ }^{187}$ It would mean, for example (to borrow a cast of characters familiar from Guerin $^{188}$ ), that the Musqueam Band and its members would be subject to British Columbia's limitations legislation in their efforts to protect their reserve land from third party damage, but that the Shaughnessy Heights Golf Club, which operates under lease upon a conditionally surrendered portion of the Musqueam reserve, would not. On Aboriginal title lands, where the land-related provisions in the Indian Act have no application, it would mean that statutory Indians were subject to provincial restrictions on the use, enjoyment, possession, and disposition of their ancestral lands, but that non-Aboriginal people, who might well have no legal right whatever to use or occupy those lands, could operate free of those constraints. It would mean that different mainstream legal arrangements governed the property rights in Aboriginal title lands of statutory Indians and, e.g., the Inuit. And it would mean that Parliament, by manipulating the statutory definition of "Indian," could control almost at will the intendment on such lands of whole provincial land law regimes.

Imposing the regulatory burdens related to such lands uniquely on a class of people defined for the purpose as "Indians" not only seems troubling and counterintuitive, it

Subject, as always, to the various s. 88 exceptions and to any differences between federal and provincial enforcement policy, practice, and capacity. See supra notes 60-67 and accompanying text.

14 See supra note 24. Compare Alphonse, supra note 125 at 421 (para. 61).

I8s See supra notes 127-29 and accompanying text; McNeil, "Section 88," supra note 124 at 24-25, n. 77.

IN: Douglas Sanders was the first to point this out in print: see Sanders, supra note 149 at 156, n. 14 (at 287). See also McNeil, "Section 88," ibid. at 24-25.

in For similar views, see the sources cited in the previous note.

1\%x Supra note 144. 
also appears to discriminate in a way that $s .15$ of the Charter ordinarily prohibits. ${ }^{189}$ Aiming such requirements uniquely at the exercise of ancestral rights in Aboriginal title lands would almost certainly also require justification pursuant to s. 35(1) of the Constitution Act, 1982. In neither case can I think of a basis on which the federal government could justify such a difference in treatment. ${ }^{190}$

\section{d. Summary}

We are driven, then, to reconsider the narrower view of s. 88's application: the view that it does not apply provincial land regulation measures to s. 91(24) lands, even to control the conduct or interests of statutory Indians. ${ }^{191}$ Whether or not some provincial land measures might operate to Indians' benefit if given general application on s. $91(24)$ lands, ${ }^{192}$ it seems almost certain that no such measures could do so if applied on such lands exclusively to statutory Indians.

Again, we face an unhappy choice between unpalatable options. The narrower interpretation leaves room for some important gaps in the regulation of uses of, and interests in, reserve lands and risks leaving wholly unregulated (at least by mainstream law) the interests in, and uses of, significant portions - some perhaps still unidentified - of s. 91(24) lands off reserve. The broader reading extends provincial land regulation

According to s. 15(1) of the Charter, "[e]very individual is equal before and under the law and has the right to the equal protection and equal benefit of the law without discrimination and, in particular, without discrimination based on race, national or ethnic origin, colour, religion, sex, age or mental or physical disability."

It is arguable that s. 91(24) of the Constitution $\mathrm{ACl}, 1867$, which authorizes federal arrangements that treat Indians differently, insulates the federal arrangements enacted pursuant to it from scrutiny under s. 15(1). See K. Wilkins, “... But We Need the Eggs: The Royal Commission, the Charter of Rights, and the Inherent Right of Aboriginal Self-Government" (1999) 49 U.T.L.J. 53 at 58-59, nn. 25-26. This was not the result in Corbière v. Canada, [1999] 2 S.C.R. 203. There, the Supreme Court used s. 15(1) to strike down an Indian Act provision (s. 77(2)) that had distinguished invidiously between band members living on reserve and those off reserve. Different considerations may arise in respect of federal measures that treat Indians differently from nonIndians. At present, however, this line of argument seems to hold no interest for the federal government: see "Speaking Notes for the Honourable Robert D. Nault to the Assembly of First Nations Confederacy of Chiefs" (Ottawa, 9 December 1999) (http://www.inac.gc.ca/news/ sep99/99172bk4.html).

This is true, I believe, even if one accepts that $\mathbf{s .} 88$ can ever facilitate justified infringement of existing Aboriginal rights. (My view, again, is that it cannot; see supra note 170.)

This scenario, however, helps illustrate why, in my view, it is s. 88 itself, not the different provincial measures it incorporates, that stands in need of justification under s. 35(1) of the Constitution Act, 1982. In this situation, unless one's gaze is focused on s. 88, one overlooks the principal constitutional objection: the fact that the only interests in Aboriginal title lands that the provincial measures, as incorporated, are regulating are the protected interests of statutory Indians. See generally "Section 35 Rights," supra note 43 at 226-32.

"It is a well established principle of statutory interpretation that the legislature does not intend to produce absurd consequences": Re Rizzo \& Rizzo Shoes, [1998] 1 S.C.R. 27 at 43 (para. 27). See also, e.g., Berardinelli v. Ontario Housing Corporation, [1979] I S.C.R. 275 at 284: "When one interpretation can be placed upon a statutory provision which would bring about a more workable and practical result, such an interpretation should be preferred if the words invoked by the Legislature can reasonably bear it." 
schemes to s. 91(24) lands, but only in application to statutory Indians. The former approach betrays $\mathrm{s}$. 88's pretensions to comprehensiveness; the latter, its pretensions to harmonization. The former threatens mainstream expectations that a stable and predictable legal regime will govern transactions concerning what turn out to be $s$. 91(24) lands; the latter's answer to that expectation is a scheme that offers only invidiousness and borders on incoherence.

\section{E. “... EXCEPT TO THE EXTENT THAT SUCH LAWS ARE INCONSISTENT WITH THIS ACT OR ANy ORder, RULE, REgulation OR By-LAW MADE THEREUNDER, ..."}

Like the earlier phrase "and any other Act of the Parliament of Canada," and for the same reasons, this phrase ensures that the Indian Act's own provisions, and the provisions of any subordinate legislation passed pursuant to it, prevail over any conflicting provincial measures incorporated as federal law under s. $88 .^{193}$ In Derrickson, the Supreme Court adopted and applied for this purpose the same paramountcy test that governs federal and provincial laws when both apply as such. ${ }^{194}$ There is every reason to assume that the test for paramountcy in constitutional law, as it develops from time to time, will continue to apply here as well.

\section{F. “... ANd EXCEPT TO THE EXTENT that SUCH LaWS MAKe Provision for ANy Matter for Which Provision is MAde By or UNder This ACt."}

These are the words that prompted the Supreme Court to conclude, in Dick, that s. 88 as a whole cannot just declare the terms on which provincial laws will apply, of their own force, to statutory Indians. It is the Constitution, as interpreted, that prescribes when and why provincial laws must give way in order not to interfere with the operation of federal schemes. It is not open to Parliament to give its own statutes greater protection from provincial interference than the Constitution already gives them. The kind of enhanced priority that these closing words provide is available to Parliament only as against other federal laws. ${ }^{195}$

These consequences constrain in two ways our understanding of these closing words. They clarify that these words do indeed confer on the Indian Act, and on arrangements enacted under it, ${ }^{196}$ extra protection from the effects of the relevant provincial laws, beyond what would be available under the usual paramountcy rules. ${ }^{197}$ And they

\footnotetext{
193 Sce supra notes 92-96 and accompanying text.

194 See Derrickson, supra note 52 at 299-303.

195 See Dick, supra note 39 at 327-28. See also supra notes 53-54 and accompanying text.

I\% It seems clear from s. 88's text that this extra protection extends only to provisions made "by or under" the Indian $A c t$, not to other federal legislation. Other federal legislation, regulations, and bylaws - even other federal laws in relation to Indians or Indian lands - must, unless they themselves provide otherwise, coexist with the incorporated provincial arrangements unless those arrangements interfere sufficiently to trigger standard paramountcy doctrine. See, e.g., supra note 54 and the sources cited therein.

197 In Derrickson, supra note 52, released a few months after its decision in Dick, supra note 39, the Supreme Court made this conclusion still more explicit, citing with approval Peter Hogg's conclusion that "[i]t seems probable ... that the closing words of s. 88 go further than the
} 
confirm that this extra protection is available only against the effects of those provincial laws whose application to Indians depends on incorporation pursuant to s. 88. It has nothing to do with any provincial laws that apply, as such, to Indian lands or to s. 91(24) Indians. ${ }^{198}$

But what extra protection do these closing words provide? My own sense is that they reconfigure the burden of proof as it operates within conventional paramountcy doctrine.

Ordinarily, as we saw above, the courts assume, until persuaded otherwise, that federal and provincial laws can operate together; the burden is on the person seeking to neutralize the provincial scheme to prove that it interferes with the federal one. Where there is no express contradiction between them, the only option is to show that the provincial measure interferes with the manifest objectives underlying the federal scheme: that, to take the best example, the federal scheme was clearly intended to operate to the exclusion of any other regulatory measures. ${ }^{199}$

To me, s. 88's closing words create a strong presumption the other way. When federal authorities, or band councils, enact particular schemes within or pursuant to the Indian Act, these words instruct the courts to presume that those schemes are meant to operate to the exclusion of any overlapping provincial arrangements that $s$. 88 incorporates; those challenging the provincial arrangement need not offer evidence of that intention, let alone demonstrate it. Any competent "substantive scheme or arrangement" ${ }^{200}$ set out in an Indian Act provision, regulation, or bylaw, therefore, routinely displaces, to the extent of any overlap, any incorporated provincial scheme. This means, for example, that permissive band council bylaws, where authorized by and validly enacted under the Indian $A c t,{ }^{201}$ will almost always override, on the reserves to which they pertain, ${ }^{202}$ any related prohibitions contained in incorporated provincial measures about the same matter, unless a bylaw specifically indicates otherwise. Similarly, administrative or enforcement arrangements that band councils validly enact to support their own measures will, other things equal, preclude recourse to any alternative

paramountcy doctrine and will render inapplicable to Indians some provincial laws which would have been applicable under the general law": see Derrickson, ibid. at 300, quoting Hogg (2d ed.), supra note 97 at 562 . See Hogg, supra note 51 at 570 , for the reference in the current edition of Hogg's text.

See Hogg, ibid. at 570-71.

See, e.g., supra note 54 and the judicial decisions cited therein.

"[T]o 'make provision' as is contemplated by $s .88$ is to create a substantive scheme or arrangement" with respect to it, not merely to pass legislation authorizing regulations or bylaws about it: Martin, supra note 148 at 13. Compare, to similar effect, $R$. v. Charles, [1998] 1 W.W.R. 515 (Sask. Q.B.) at 522-23 (paras. 25-28). The mere fact that the Indian Act confers powers to make regulations or bylaws about certain matters, therefore, is very probably not enough, on its own, to displace incorporated provincial arrangements that deal, in the meantime, with those same matters. It is only when the federal government, or the band council, actually uses those powers that the closing words of $\mathrm{s} .88$ come into play in respect of them.

See Indian Act, ss. 81-86.

A band council's bylaws have no application outside the boundaries of that band's reserve: see supra note 137. 
mechanisms provided in overlapping incorporated laws. To displace an overlapping measure, all they have to demonstrate is the overlap.

But how can courts tell, in difficult cases, whether and to what extent there is overlap? This turns out to be a harder question than it may at first seem.

Displacement occurs, the closing words tell us, when, and to the extent that, the Indian Act provision, regulation, or bylaw makes provision for the same matter as the incorporated provincial scheme. This follows, I think, from the words "makes provision for any matter for which provision is made..." What does it mean?

In Canadian law, the word "matter" has a particular spin and history because of its use in the opening words of both ss. 91 and 92 of the Constitution Act, 1867. Each of our levels of government has exclusive authority to make laws and engage in state action in relation to the "matters" that come within the classes of subjects assigned exclusively to it. ${ }^{203}$ "Matter," in this sense, is the defining subject matter of a measure or provision: what it is "really about." Except where the Constitution provides specifically for shared provincial and federal authority, ${ }^{204}$ each "matter" capable of being a subject of government activity is within the capacity of one level of government or the other, but not both. ${ }^{205}$

This seems to have been part of what troubled Laskin C.J.C. in Natural Parents about s. 88's closing words. He seems to have worried that those words might be read to create, by statute, a broader scheme of concurrent federal and provincial authority. It was in significant part for that reason that he regarded s. 88 as incorporating provincial law by reference. ${ }^{206}$

In fact, this problem goes even deeper than Laskin C.J.C. seems to have realized. If "matter" in $\mathbf{s .} 88$ means what it means for division of powers purposes, then there will never be an occasion when its closing words can come into play, because there will never be an occasion - leaving aside those rare instances of concurrent authority when both levels of government can each "make provision" for the "same" "matter"; if both try to do so, one measure or the other must be invalid. ${ }^{207}$ If it is the Indian Act-based measure that is invalid, it will be in no position, obviously, to displace anything. And if the provincial measure is the invalid one, then no question of overlap

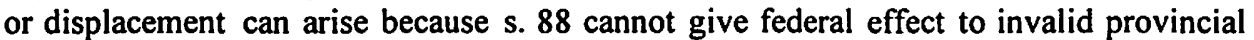
laws. ${ }^{208}$ Far from giving enhanced protection to valid Indian Act-based schemes, the

Section 91 says, in part, “... it is hereby declared that (notwithstanding anything in this Act) the exclusive Legislative Authority of the Parliament of Canada extends to all Matters coming within the Classes of Subjects next hereinafter enumerated ..."; s. 92 begins with the words "In each Province the Legislature may exclusively make Laws in relation to Matters coming within the Classes of Subjects next hereinafter enumerated..." See Constitution Act, 1867, ss. 92A(2),(3), 94A, 95.

See, e.g., Hogg, supra note 51 at $341-45$.

See Natural Parents, supra note 36 at 759-64, especially 763-64, Laskin C.J.C. (for the plurality), discussed briefly in supra notes 38,53-54 and accompanying text.

See, e.g., Bell 88, supra note 45 at 766, 839-43, 852-55.

See supra note 51 and accompanying text. 
closing words, on this view at least, can really give such schemes no protection at all, because no provincial measure that $\mathrm{s} .88 \mathrm{can}$ incorporate can possibly ever run afoul of them.

We know that this result cannot be right; the Supreme Court, as we have seen, has based almost its entire approach to interpreting s. 88 on the premise that those closing words offer extra protection to some federal laws. ${ }^{209}$ But if the "matters" that interest us in $\mathrm{s.} 88$ are something other than the "defining characteristics" we have learned to use in constitutional law, no one, so far as I know, has yet figured out what they are.

Once we can say what matters are, we need to try to clarify how - and at what level of generality - we are to individuate them. If we characterize them too broadly, then we risk marginalizing $\mathrm{s}$. 88 as a whole, because too few, if any, provincial measures will be able to pass its final test. "[E]xcept to the extent" here has to mean something. If we differentiate too minutely among them, we frustrate - again - the evident aim of its closing words to ensure that Indian Act-based schemes are fully protected against the risk of disturbance from provincial measures that, in practice, regulate matters essential to Indianness.

Only in Derrickson has the Supreme Court said anything on this question. ${ }^{210}$ It said there, without elaboration, that "[c]ompensation in lieu of a division of property [on separation] is not a matter for which provision is made under the Indian Act"; 211 as a result, provincial measures authorizing such compensation could apply in respect of particular land on a reserve even though the court had earlier held, for related reasons, that related provisions authorizing division of the interest in that land could not. ${ }^{212}$

As for lower court decisions, there are few, and none recent. All of them date from before the Supreme Court decided Dick ${ }^{213}$ and Derrickson, ${ }^{214}$ and none involves a provincial measure that we would now regard as engaging $5.88 .{ }^{215}$

See supra notes $195-98$ and accompanying text.

In Natural Parents, supra note 36, Laskin C.J.C., after calling specific attention (at 763-64) to s. 88's closing words to support his conclusion that the section incorporates provincial law by reference, ignored them completely when deciding whether the relevant provincial legislation B.C.'s Adoption Act - was sufficiently compatible with the rest of the Indian Act to apply to Indians. "[A]doption legislation," he said, "is ruled out only to the extent that it is inconsistent": ibid. at 766.

Derrickson, supra note 52 at 304.

Ibid. at 301-303 (provincial rules for division of family property on separation not enforceable on reserve because they interfere with the discretion of the Minister of Indian Affairs, pursuant to s. 24 of the Indian $A c t$, to approve all transfers of possessory interests in reserve lands).

Supra note 39.

Supra note 52.

Two of these decisions may deserve brief mention here. In $R$. v. Peters (1966), 57 W.W.R. 727 (Y.T. C.A.) [hereinafter Peters], the Yukon Territory Court of Appeal held that an underage Indian could not be charged with offences under the Yukon Territory Liquor Ordinance because the Indian Act addressed the issue of Indians' use and possession of intoxicants, even though it did not prohibit Indian minors from using alcohol. In its view, s. 88's closing words "should be given a broad and liberal interpretation in order to give effect to the intention of parliament which has clearly made provision, by the Indian $\mathrm{ACl}$, for the matter of the use and possession of intoxicants by Indians" (ibid. at 730). In Re Baptiste; Director of Maintenance and Recovery v. Potts, [1979] 
Until we have clearer, more recent signals about what matters are, and about how broadly or narrowly courts will characterize them, and why, we can have no trustworthy sense about what practical difference, if any, these closing words will make in adjudication.

\section{Conclusion}

Perhaps the greatest irony about $\mathrm{s} .88$ is that it may well have been intended, at least in part, as what insiders call a "housekeeping amendment." There still exists at least one original copy of Bill 79 that includes, next to some provisions, typewritten marginal notes interleaved with the official explanatory notes included in the printed versions of the bill. ${ }^{216}$ Next to 5.87 (now 88) in this copy of the bill is a typewritten note that reads as follows:

87. This is new and the effect of this section is to clear a long-standing doubt as to the application of provincial laws to Indians. The present Act is silent on the subject, which has resulted in considerable legal confusion.

Section 88 of the Indian Act has been part of our law now for almost exactly half a century: more than enough time to permit a considered appraisal of its contribution. If dispelling doubt and confusion was indeed its purpose, I doubt that very many today would agree that it had succeeded in fulfilling it. By any relevant standard, its contribution has been almost entirely negative.

Introduced with little explanation, enacted with next to no debate, s. 88 reflects confusion and encourages difference of view about the extent of the provinces' own authority to regulate what Indians do and what happens on and to Indian lands, and about the extent of federal power to facilitate, and to channel and limit, that authority. As might be expected, it has not fit comfortably within the framework the courts have developed more recently for dealing with these constitutional questions. As a result, courts found it uncommonly difficult to ascertain how s. 88 really operates: as a declaration of limits ori the application to Indians of free-standing provincial measures or as a structured incorporation of those measures to ensure, within limits, that they apply.

6 W.W.R. 560 (Alta. Q.B.), on the other hand, the court held (at 568-69) that narrowly focused Indian Act provisions for the support of an Indian's family in case of desertion (s. 68) do not preclude resort to broader enforcement measures under provincial family support legislation, except in respect of the very classes of assets that the Indian $\mathrm{ACt}$ makes subject to ministerial discretion. For discussion, itself from before either Dick or Derrickson, of these and other early cases, see Hughes, supra note 149 at 93-97. For further discussion of Peters, see Lysyk, supra note 57 at 545-47 and McNeil, "Section 88," supra note 124 at 31-32.

This copy belongs to John Leslie, manager of DIAND's Claims and Historical Research Branch, who obtained it while doing research for his own Ph.D. dissertation: see Leslie, supra note 3. According to Leslie (personal conversation, 16 June 1999), this working copy most likely belonged either to T.R.L. McInnes, secretary, at the time, of the Indian Affairs Branch, or to L.L. Brown, a junior departmental solicitor with the branch. Both, most probably, were players in the process of developing Bills 267 and 79 . I have, at present, no evidence, though, whether these typewritten margin notes were considered departmental views of the purposes of some sections or just the personal views of one man about them. 
The Supreme Court finally solved that problem - perhaps as well as it possibly could have, under the circumstances - in Dick by splitting the difference. ${ }^{217}$ Understood within the larger constitutional framework, however, the court's solution gives rise to unacknowledged, inconvenient, and profoundly difficult problems concerning the powers, costs and mechanisms of enforcement of the provincial standards that measures that s. 88 incorporates. At the same time, it seems, of necessity, to deprive the words "laws of general application" of any meaningful function within the section as a whole, except to screen out measures whose territorial application is not uniform. (And come to that, why should it matter, from a policy standpoint, whether a provincial law whose effect is to regulate Indianness does so throughout the province or only within, say, Greater Winnipeg?)

It was s. 88's closing words, above all, that shaped the Supreme Court's understanding of the provision as a whole. Those words, it seems clear, were intended to give Indian Act-based substantive schemes enhanced protection, beyond that which the Constitution itself would have provided, from the risks of disturbance resulting from provincial measures dealing with the same matters. Neither the courts nor these words themselves, however, have given us any clear guidance in recognizing the circumstances in which that extra protection is to be available. And if we take seriously the constitutional significance of the concepts they employ, these closing words may well confer no extra protection at all, because the kinds of situations that they appear to envisage cannot, for constitutional reasons, occur.

Finally, s. 88 frustrates coherent analysis of its impact on provincial measures that govern rights and interests in land: measures that, for constitutional reasons, could not apply, as such, in respect of s. 91(24) lands. A literal reading of s. 88 would give such measures federal effect and application on such lands, at least in the absence of any other arrangement anchored in the Indian Act; the effect of such an interpretation, however, would be to render such measures applicable on such lands exclusively to those whom the Indian Act defines as "Indians." The more popular alternative understanding of the provision avoids that perverse result by deeming such measures altogether ineligible for incorporation pursuant to s. 88; its effect, though, would be to eliminate any current mainstream mechanism for regulating any s. 91(24) lands or land matters that the Indian Act itself has left unaddressed. Neither consequence seems compatible with rational suppositions about the purpose of s. 88 .

It would, of course, be unfair to suppose that Parliament intended us to inherit so much confusion when it gave us s. 88 in 1951. These are extremely difficult issues at the best of times, and we know a lot more now than they did then about the essential constitutional doctrines that define and delimit the provinces' powers to affect Indians' lives. At least some of the interpretive problems s. 88 poses resulted, or got worse, because of subsequent constitutional or jurisprudential developments.

It is fair to say that s. 88 is now in serious need of legislative reconsideration. By any reckoning, it has created substantially more legal problems than it has solved. It is, 
as Brian Slattery, Kent McNeil, and I have each argued, "of doubtful constitutional validity" when and as it operates to restrict the exercise of existing Aboriginal rights. $^{218}$ And it rests, from a policy standpoint, on contentious and unarticulated assumptions: about which s. 91(24) Indians and which aspects of their lives stand in need of mainstream regulation and by whom; and about when, where, and why such regulation is appropriate. These assumptions, and the questions that they purport to answer, deserve re-examination and reflection in light of contemporary law and experience. Hard cases, one often hears, make bad law, but the converse proposition is true as well.

See supra note 170 and the sources cited therein. My principal reason for doubting s. 88's constitutional soundness is that it makes no allowance whatever for Aboriginal rights, either by according these rights some statutory priority (as it did for treaty rights) or by requiring prior federal review of the provincial measures it incorporates to ensure that they meet some threshold of sensitivity or proportionality in their impact upon such rights. Instead, it simply assumes that all provincial laws that meet its requirements ought to govern statutory Indians, even - indeed, especially - in matters, such as the exercise of Aboriginal rights, that are characteristic of them as Indians. See "Section 35 Rights," supra note 43 at 226-33, especially 232-33. 